\title{
Otto Bauer and His Time
}

During the night between 3 to 4 July 1938, Otto Bauer died in the Rue Turgot in Paris. ${ }^{1}$ He was only 57 years old. His close friend and long-time editorial assistant of Vienna's Arbeiter-Zeitung, Otto Leichter, who was called to Bauer's deathbed by his wife Helene, wrote: 'There was no doubt to anyone who was able to spend Bauer's last months with him that he died of a broken heart in the truest and saddest sense.'. Bauer passed away believing that he was responsible for the defeat of the party and unhappy about his forced emigration and separation from his native country. He was also distressed over the fate of his comrades and the new party, the Revolutionary Socialists of Austria, after Hitler's Anschluss (annexation of Austria). His death came during an unfavourable period for the workers' movement: the threat of war was becoming increasingly likely, the masses were disillusioned with bourgeois democracy, the totalitarian system of the USSR had consolidated itself, and divides within

1 This chapter was originally written for Polish readers who were scarcely familiar with Otto Bauer and the political background in Austria from 1889-1938. Hence, this English-language edition only contains an abridged version. I believe that it serves as (1) an introduction to further factual analyses, and (2) a summary of the extensive materials about Bauer's works and political activity, as well as the politics of the SDAP, which are scattered across many Germanlanguage studies and sources. I based this chapter on biographical and historical sources including: Ackermann 1969; Botz 1978; Bauer 1961; Braunthal and Peiper 1975; Böhm 1974; Kulemann 1979; Leichter 1970; Mozetič 1983 and 1987; Leser 1968; Singer 1979; Reimann 1968; Weinzierl 1984; protocols of the SDAP congresses, conferences of the Labour and Socialist International bureau, Bauer's speeches and letters, and, finally, my earlier works. In preparation for the English-language edition, I was able to include details about Bauer's life and political activity drawing on the outstanding and challenging Otto Bauer biography by Ernst Hanisch, Der große Illusionist (The Great Illusionist) of 2011. I wholeheartedly recommend this work, which is written in a lively and accessible prose.

2 Leichter 1970, p. 14. Based on the memoirs of Leichter and doctor and writer Richard Berczeller, Hanisch states that Bauer suffered a heart attack in his office on 2 July 1938. He did not want to go to the doctor because, as a notorious chain smoker, he feared that he would be banned from smoking entirely. On 3 July, he began to feel better and had supper with Fritz Adler's family. That night, however, his condition weakened, and he had trouble breathing. His wife Helena called a doctor and their friends Theodora and Lidiê Dan, who sent Bauer to a Russian doctor. When the doctor arrived, he found Bauer dead in his bed. Likewise, Leichter arrived at the hotel after Bauer's death - see Hanisch 2011, pp. 373-4.

(C) EWA CZERWIŃSKA-SCHUPP, 2017 | DOI: 10.1163/9789004325838_002

This is an open access article distributed under the terms of the CC-BY-NC License.

Ewa Cżerwińska-Schupp - 9789004325838 Downloaded from Brill.com04/26/2023 01:33:30AM 
the Social-Democratic movement were widening. Moreover, there was a lack of developed organisational principles and tactics for the workers' struggle against fascism. Bauer's funeral on 6 July 1938 at the Père Lachaise Cemetery in Paris, which commenced with a rendition of the Internationale, turned into a demonstration of workers' solidarity. ${ }^{3}$ Many renowned activists of the international labour movement, party comrades, and hundreds of workers were present. As an homage to Bauer and his legacy, his ashes were placed next to the urns of the Paris Commune fighters, then wrapped in a red flag, covered in red flowers, and passed to two young Austrian socialists. ${ }^{4}$ Speeches were held by Léon Blum, who represented the French Socialist Party, Friedrich Adler, a friend and colleague of Bauer's, Gustav Richter (Joseph Buttinger), the chair of the Revolutionary Socialists of Austria, and Louis de Brouckère, the chair of the Labour and Socialist International. Blum's words were a fitting résumé of the aspirations that had defined the entire life of the departed theorist and politician: 'Each and every one of us feels that Bauer was cut from the same cloth as leaders such as Jaure, Guesde, and Vaillant: always illuminating action through theory, always invigorating theory through action. ${ }^{5} \mathrm{He}$ did not merely want to be a socialist in parliament. Rather, he viewed his duties as issuing the guidelines of historical materialism when investigating socialist transformation and utilising the results to determine the strategy and tactics of the workers' party. They served to improve the economic and political situation of the proletariat and allied groups and, ultimately, herald the victory of socialism. Even the illegal periodical of the Communist Party of Austria, which was hostile towards Social Democracy, printed a note after the funeral, attesting to Bauer's undisputed authority as an ideologist and theorist of the SDAP. ${ }^{6}$

Otto Bauer was born on 5 August 1881 in Vienna. He was the first-born son of a wealthy textile factory owner and merchant in north Czechia, Philip Bauer, and his wife Käthe (born Greber). At that time, Otto's family, including his sister Ida, who was a year younger than him, lived in the Jewish district, Leopoldstadt, and later changed its residence several times. The roots of his father's

3 Weinzierl 1984, p. 11.

4 See 'Zum Tode Otto Bauers', $R$ s Korrespondenz in Diaries and Memoirs.

5 Ackermann 1969, p. 6.

6 'Bauer stamped his personality on an entire period of the Austrian workers' movement ... To honour Otto Bauer's work critically, to overcome his errors critically remains a task for us. The greatness of this task testifies to the greatness of the man who departed from us'. Weg und Ziel 7, p. 249 . 
family were based in Czechia, where Bauer's Jewish grandparents originated. ${ }^{7}$ According to Braunthal, Otto grew up in an atmosphere that was conducive to his predisposition: free from material worry, pampered by his mother who dedicated her entire time to the family, and his father, who was known for his jovial personality and liberal views. ${ }^{8}$ The atmosphere at home was one of ideological tolerance, ${ }^{9}$ mainly due to Bauer senior, who was a member of a Masonic lodge. ${ }^{10}$ The family read the works of German and French writers and philosophers with pleasure and cultivated an interest in theatre and the arts. His father's illness was the reason as to why Otto frequently changed schools, attending schools in Vienna and Meran. He finished grammar school in Reichenberg. In all schools, he was the best in class. ${ }^{11}$ In this period of his life, he had three passions: the study of German culture and history, foreign languages (he had a good command of Latin and Greek, knew Czech from early childhood, spoke French and English fluently, learned Serbo-Croatian for his studies of the history of the Balkans, and later learned Russian in a prisonerof-war camp), and sports (particularly alpine hiking, which would remain his hobby for the rest of his life). ${ }^{12}$ When attending grammar school, he began to take an interest in socialist literature. He wrote a letter to Kautsky on 19 May 1904, and Anti-Dühring, The Communist Manifesto, and Capital were discussed among his circle of friends. ${ }^{13}$

In accordance with his father's will, which would entrust Otto with the management of the factory, he took up law studies at Vienna University in the winter

Their three sons quickly assimilated and took up respectable social positions. Ludwig was an acclaimed Viennese lawyer. The inspiration behind Bauer's interest in socialism, Karl, was a well-known merchant. Otto Bauer's father Philip was the owner of a textile factory in Warnsdorf. See Braunthal 1975, p. 3. Ibid.

9 As an adult, Bauer defended the freedom of religion and remained respectful towards it. He did not quit the Jewish religious community of Austria, the Israelitische Kultusgemeinde, out of respect for the religion of his ancestors and his solidarity with Jews. See Hanisch 2011, pp. 50-7.

10 'He belonged to the Friedrich Schiller lodge of Vienna' (our translation). Hanisch 2011, p. 22.

11 As Hanisch writes, 'Bauer was blessed with an outstanding mind - inquisitive, hungry for knowledge, and linguistically gifted' (our translation). Hanisch 2011, p. 29.

12 See Singer 1979, p. 106.

13 The youthful fascination with the classics of Marxism reflected, above all, a moral indictment of capitalist social relations, a loss of faith in the values of bourgeois culture, and an affirmation of the intellectual freedom of the individual as understood by Kant. In reference to Marx's prognoses of social development, Bauer hoped for the victory of socialism based on the realisation of this idea. 
semester of $1900-1 .{ }^{14}$ At the turn of the century, Vienna was not only a centre of the scientific, cultural, and political life of the Austro-Hungarian monarchy, but also a significant focus of the socialist movement led by Victor Adler since 1889. ${ }^{15}$ The policies enacted by Franz Joseph I of Austria and the governments of Eduard Taaffe, Count Kasimir Felix Badeni and Ernst Koerber turned the Habsburg monarchy into a modern capitalist state economically, and a constitutional state in the administrative realm. The convergence of the aims of monarchic state power and the interests of Social Democracy was typical of that state. The former was favourable to political circles that desired stronger links between Austria-Hungary and Germany; in the broadest sense, it was also well disposed towards the advocates of federalism, who aimed to divide the monarchy into multiple federal states. The Social Democrats, meanwhile, aspired to preserve the unity of the multinational state. Each of these parties had different expectations concerning electoral reform. The Emperor hoped to empower the government and empire, while the Social Democrats hoped to strengthen the working class. Yet both found it important to recognise parliament as the platform of political and economic decision-making. It was precisely the SDAP's overestimation of the significance of parliament that later led to its downfall: it misread legal measures as guaranteed victories for the working class. At the turn of the nineteenth and twentieth centuries, however, Victor Adler's tactics corresponded with the consciousness of the proletariat at the time. They involved the unification and reinforcement of the workers' move-

14 Bauer's years of study were characterised by his titanic diligence and distinctly ascetic lifestyle, which he would maintain for the rest of his life. He was a rather unsocial, radical teetotaller who seldom forged friendships and kept people at a distance, which many interpreted as conceit. As Hanisch confirms, Bauer enrolled in Roman and German law, history of Austrian law, and philosophy, and additionally, history of economy in the second semester and political economy and general statistics in the third. He had an academic gap year from $1902-3$ in order to do his military service. Upon returning to university, he focused his attentions on national economics, political economy, and Austrian commercial law. See Hanisch 2011, pp. 68-9. In later years, Bauer broadened these interests by his own extensive studies, which was reflected in his work.

15 The unification of the workers' movement in Austria took place at the Hainfeld congress from $3_{1}$ December 1888-1 December 1889, in which delegates from socialist groups of various nationalities participated. In accordance with the programme authored by Victor Adler, acquiring universal suffrage was regarded as the ultimate objective of the class struggle. Accordingly, the question of revolution was postponed indefinitely. Sheer numbers testify to the strength of the labour movement at the time: 150,000 members, 540,000 trade union members, one million votes, eight seats in parliament. See Abendroth 1965, p. 74 . 
ment, the struggle for political and social reforms within the legal framework of the existing state, and a politics of compromise with the bourgeoisie and aristocracy. Adler's goal was to transform the empire into a democratic multinational state. His means to this end were the struggle for universal suffrage, the consolidation of the party's position by legal means, and, later, winning the majority of seats in parliament. According to the Social Democrats, the prerequisites for the victory of socialism in the distant future were the development of class consciousness and greater historical maturity of the masses, their will to transform the constitutional order, and advanced economic conditions. The party wanted a peaceful revolution that would preserve the democratic and cultural gains of the capitalist state. The political trajectory and interpretation of socialist ideology suggested by Adler at the 1901 congress secured the SDAP support from the working class and the sympathies of the progressive intelligentsia. Its electoral victories garnered the attention of students - in parliament, the SDAP came second to Karl Lueger's Christian Social Party, which represented the bourgeoisie, petty bourgeoisie, and peasantry.

At Vienna University in the early 1890 s, the philosopher Max Adler founded the Free Association of Socialist Students and Academics, which counted the future Austromarxists, Karl Renner and Rudolf Hilferding, among its members. ${ }^{16}$ In 1894 , this group merged with the academic debating society Veritas, in which Adler and Ernest Pernersdorfer were also involved. Under the influence of the Social Democrats, the Free Association became a powerful centre for self-education. In $1894-5$, its members began to collaborate with the academic historians Ludo Hartmann and Karl Grünberg, with whom they founded the Sozialwissenschaftlicher Bildungsverein (Social Sciences Education Society). Bauer joined both organisations. He was not only motivated by moral considerations when joining the socialist movement. His study of Marxism, Capital in particular, persuaded him that Marx's historical materialism was theoretically correct and illuminated the path for historical and social development. ${ }^{17}$ He joined the so-called Bernstein debate and defended Marx's basic premises against the attacks of revisionists. Three legacies inspired his Marxist positions on the socio-economic phenomena of the time: the philosophy of Kant; the methodological premises of positivism and scientism; and the Austrian school of political economy, including the views of Eugen Böhm-Bawerk, whose seminar he participated in.

\footnotetext{
16 Haussmann gives dates with respect to the beginnings of the socialist movement at Vienna University - see Haussmann 1979, pp. 180-2.

17 Compare Mozetič 1987 , p. 23.
} 
Bauer's philosophical and social worldview became more sophisticated after he joined the educational society Die Zukunft, the first workers' school of Vienna founded in 1903. Its co-founders Max Adler, Karl Renner and Rudolf Hilferding (who were some 10 years Bauer's senior), and its later members Gustav Eckstein, Friedrich Adler, Wilhelm Ellenbogen, Robert Dannenberg, Anton Hannak and Bauer created the intellectual and ideological tendency that later became known as Austromarxism. Most of them were from bourgeois families, mainly within the Jewish intelligentsia, while Renner and Hannak hailed from peasant backgrounds. Actively participating in workers' school and party organisations, they also intended to overcome the workers' scepticism towards intellectuals in the socialist movement. ${ }^{18}$ Their aim was to fuse the original ideas of Marxism with philosophical, sociological, economic and legal theories and political positions which were dominant within bourgeois ideology: positivism, naturalism, social Darwinism, legal normativism, the heritage of the Austrian school of national economics, reformism, and syndicalism. German nationalism played a role in their attempts to merge these concepts to a degree. It was most evident in their reluctance to integrate any scientific and political systems that had originated from outside the remits of German culture. At least, not without first melting them in the polemical fires and then remoulding them to suit German national consciousness. Their standpoint, which became the cornerstone of Social-Democratic political practice, was in fact a collection of theories linked solely through the affirmation of socialism, which was conceived abstractly as a synthesis of general humanist values. The fact that the founders of this school actively participated in the struggles of the workers' movement influenced the theoretical concepts they adhered to. Amongst Austromarxists, there was a certain division of labour, which affected the subject of research. Max Adler focused on philosophical, ideological and ethical matters; Hilferding attended to economic problems; Renner concentrated on law, the state order and sociology; and Bauer dedicated himself to sociological, historical and socio-political aspects, as well as

18 They represented the third generation of Marxists, who were immersed in the classics of Marxism, as well as the popularising works of Kautsky. It is questionable as to whether Kautsky really belonged to the Austromarxist tradition, as Trotsky argued - see Trotsky 2011, pp. 229-30. Kautsky was a member of the Austrian Social Democrats until he departed for Zurich in 1880, yet he never abandoned his close co-operation with Victor Adler. His evaluation of Bolshevism, sympathy for the Mensheviks, and concept of socialist revolution met with the full recognition of the Vienna group, although he had no organisational ties to it. 
philosophy and economy. After Adler's death in 1918, Bauer determined the ideological and programmatic course of the SDAP.

The influence of contemporary Vienna on their theories cannot be overestimated. The young 'Viennese Marxists', as Karl Vorländer called them later, came of age in an atmosphere of subservience to the house of Habsburg, which was saturated in clericalism, anti-Semitism, and nationalism. In this climate, national tolerance had its limits: the superiority of the German nation had to be unconditionally recognised. All of them were students of liberal-reformist bourgeois teachers. ${ }^{19}$ Still, they let themselves be carried away by the new zeitgeist, i.e. the unconventional literary currents of the early twentieth century (Hermann Bahr, Hugo von Hofmannstahl, Arthur Schnitzler, Karl Kraus, Robert Musil), music (Anton Bruckner, Gustav Mahler, Arnold Schönberg), architecture (Otto Wagner, Joseph Hoffmann, Adolf Loos) and painting (Gustav Klimt, Joseph Maria Olbrich, Kolo Moser and Egon Schiele among others). This was all an expression of their rebellion against traditional ideas and values.

The beginning of the Viennese socialists' scientific activity was marked by the publication of the first volume of Marx-Studien by Max Adler and Rudolf Hilferding, which was dedicated to Victor Adler (the publication of this tome coincided with the end of the Social Democrats' long campaign for universal suffrage, which had persisted from 1889-1907). It contained the group's programmatic manifesto, as well as Max Adler's 'Kausalität und Teleologie im Streite um die Wissenschaft' ('Causality and Teleology in the Struggle for Science'), Renner's 'Die soziale Funktion der Rechtsinstitute, besonders des Eigentums' ('The Social Function of Legal Institutions, Particularly Property'), and Hilferding's 'Böhm-Bawerks Marx Kritik' ('Böhm-Bawerk's Critique of Marx'). The latter posed a challenge to positivism, neo-Kantianism, the psychological school of economics, and especially interpretations of Marxism held in so-called orthodox circles that were indebted to naturalism, scientism and Darwinism. Even if the authors had originally intended their concepts as antidotes to revisionism, they nonetheless testified to the birth of a new theoretical direction within the Second International.

The Austromarxists believed that Marx's development stage of capitalism belonged in the past. Applying methods and analyses derived from historical

19 An expert on this period, Norbert Leser, argues: 'Austromarxist cultural and intellectual life was not only characterised and inspired by a revolutionary Marxist and pseudoreligious, messianic element, but also by a classical pathos for education, which drew on the stock of German classicism and romanticism. It is apparent in almost all exponents of Austromarxism' (our translation). Leser 1986, p. 1986. 
materialism to the needs of contemporary society, they argued that new theoretical problems had arisen. Their openness to ideas alien to Marxism and their willingness to assimilate them gave their variation of Marxism a more modern appearance than could be said of Kautsky's canonical interpretation. Generally speaking, the philosophical and historiosophical hallmarks of Austromarxism were its sociological-historical conception of social reality, an evolutionary conception of historical progress and its categories, and epistemological, axiological and ideological pluralism. Influenced by positivism, scientism and Kantianism, its adherents viewed Marxism as a sociological and scientific theory that had not yet developed on ontological and ethical levels. Moreover, in spite of Marxism's revolutionary premises, they believed that the subjective factor had no place or justification. Their critique of naturalism stressed the importance of consciousness, ethics and culture in socio-political transformations. While agreeing that the Marxian method of explaining social phenomena and processes was imperative, they established its correctness not on the grounds of dialectics, but rather on Kant's method of transcendental criticism (Max Adler, Bauer) or, alternatively, inductionism (Renner). The Austromarxists' interests centred around the neo-Kantianism of the Baden and Marburg schools, Ernst Mach's empirio-criticism, Sigmund Freud's psychoanalysis, Hans Kelsen's pure theory of law, Böhm-Bawerk's theory of marginal utility, the works of Eduard Bernstein and Vladimir Lenin, the historical works of Karl Lamprecht and Karl Grünberg, and the sociological theories of Ferdinand Tönnies, Georg Simmel and Max Weber. Alfred Pfabigan's harsh criticism that Austromarxism reflected the intellectual poverty of Austrian philosophy at the turn of the nineteenth and twentieth centuries is problematic given its far-reaching influence. ${ }^{20}$ The period bore numerous fruits, e.g. the psychoanalytical theories of Sigmund Freud and Alfred Adler, Ludwig Wittgenstein's philosophy of language, the analytical philosophy of the Vienna Circle, and the work of unconventional thinkers such as Otto Weininger and Fritz Mauthner. The Austromarxists also creatively aided the development of the Baden and Marburg schools' neo-Kantian ideas. They crucially contributed to epistemology, the role of ideas and the conscious will in the historical process, the inseparable connection between the historical and ethical necessity in history, and the criterion of separation between natural science and social science (M. Adler, Bauer). Moreover, they re-evaluated Mach's empiriocriticism (F. Adler, Ellenbogen) and criticised vulgar materialism and revisionism. 
The socialist movement at the time was characterised by a lack of distinction between its leaders' theoretical and practical commitment. This phenomenon was particularly palpable in Austria. The Austromarxists actively participated in party affairs and organised self-education activities. They were especially close to Victor Adler and his reformist policies. Not for nothing did Yvon Bourdet's characterise Austromarxism as the unity of theory and practice - a feature that Bauer proudly emphasised during the 1927 party congress. As I pointed out in Nurt mediacji (The Current of Mediation), it was a very specific unity: the theory did not always fully take reality into account, and the practice often resulted in the opposite of what the authors expected. Although Victor Adler was not an advocate of Bernstein, he concurred that it was necessary to eschew the revolutionary road to power and concentrate on strengthening the workers' movement. He adhered to a deterministic view of the social process and believed in the inevitable self-destruction of capitalism, i.e. the advent of socialism by virtue of the 'iron laws of history', which Social Democracy could only accelerate. The material basis for this were social policies raising the living standard of the working class, the Social-Democratic parties' electoral successes, particularly in Germany, and the swelling ranks of parties and trade unions. ${ }^{21}$ The Austrian socialists scrutinised the fate and strategies of their German sister party, whose congresses they attended before becoming organisationally and theoretically independent (1869-89). Later, they continued their co-operation, e.g. via the Karl Kautsky edited journal, Die Neue Zeit. They also had contacts with socialists in other countries: Antonio Gramsci (Italy), Paul Lafargue, Eduard Vallante, Hubert Lagardelle and Alexandre Bracke (France), Georgi Plekhanov, Pavel Axelrod, Julius Martov, and Theodor Dane (Russia), Emil Vandervelde (Netherlands), Hermann Grenich (Switzerland), the Geneva Socialist Association, the workers' parties of Belgium, Denmark, Poland, Bulgaria, Romania, Australia and the United States. ${ }^{22}$

Before World War I, Austromarxism was chiefly an intellectual and ideological movement. After 1918, it became more clearly political, largely so due to the influence of its real leader, Bauer. His involvement in the communal, cultural and educational policies of the socialist government left a lasting impression on Austria's cultural and political life. Indeed, it gave birth to an entirely new and hitherto unknown spirit in conservative, bourgeois Vienna.

21 In the Reichstag elections of 1890 , the SPD won 1,427,298 votes (about 20 percent). From 1898-1912 the number of votes doubled, and in 1912 it even went up to 4,250,329 (34.8 percent). The number of trade union members rose from 680,000 in 1900 to 2.6 million in 1912. Compare Waldenberg 1976, p. 26. 
With respect to social policy, the Austromarxists advocated progress in various spheres of the sciences and arts. They fought for social legislation, general access to culture, and the reform of the educational system, including through sports. They succeeded in raising the political consciousness of poor social layers and changed their lifestyles. From the outset, Austromarxism as a political movement polarised opinions, depending on the political faction, different interpretations of Marx's doctrine, and the strategic objectives of the respective parties and social groups. ${ }^{23}$ The left of the international workers' movement (Lenin, Trotsky) berated Austromarxism for its right deviationism, pacifism, and politics of compromise towards the bourgeoisie. Conversely, the parties of the right and the Catholic press denounced it as Austro-Bolshevism, Julius Deutsch and Otto Bauer as despots, and Friedrich Adler as a murderer. ${ }^{24}$

As Bauer acknowledged in his memoirs, he spent the best years of his life in the circle, Die Zukunft, where he enjoyed a close friendship with Karl Renner, 11 years his senior. They managed to preserve their friendship despite later quarrels and political slander, including when they parted ways during World War I, as Renner was a strong advocate of war imperialism. ${ }^{25}$ Bauer held Max Adler in high esteem. He shared his vision of a new culture and new man, and

23 Specialist literature from 1970-2014 contains divergent views on Austromarxism. To list them all would exceed the limits of this work; instead it is practical to cite the main currents only. Up until the collapse of the Eastern bloc, Soviet and East German researchers, as well as the Polish author Marek Sobolewski, referred to Austromarxism as a variant of revisionism, an opportunistic movement that combined radical slogans with the renunciation of any revolutionary perspective. In Western history, two interpretations prevail; the only point they have in common is that they regard Austromarxism as part of the Marxist centre of the Second International. The first interpretation claims a theoretical unity of this intellectual tendency existed between the years 1901-14; the second views the war years as a transitional period between the first (1903-14) and second (1918-39) development stages of Austromarxism, based on its positions on World War I, the October Revolution, and the transitional stages between different political and social formations. My view is doubtlessly a minority position: I deny the ideological and theoretical unity of Austromarxism from its very inception. Austromarxism's attitude to theory and practice is another controversial point - there are three distinct responses to this matter. The first claims unity, the second claims separation, and the third denies that the former proponents of Austromarxism can be considered part of this current after becoming supporters of other political trends.

24 See Lenin 1993, p. 38; Trotsky 2011, pp. 229-30; Das Neue Reich, p. 198; Kaff 1931. Böhm comments on this in Böhm 1974, p. 35 .

25 In 1930, Bauer published an article dedicated to their friendship in Der Kampf. The theoretical and tactical differences between the two friends escaped the attention of their comrades. 
endorsed his belief in the historical mission of the proletariat. Nevertheless, he criticised Adler's inclination for Hegelian ways of thinking, his inability to recognise the real balance of class forces, and his abstraction from the politics of the day. ${ }^{26}$ Although Adler was, from the very start, more radical than the rest of the group, he exercised friendly restraint when criticising Bauer's personality and activism. Similarly, when Hilferding opposed Bauer's support for Austrian union with Germany after World War I, this did not affect their personal relationship. Political differences, which were already perceptible during the early periods of Austromarxism, intensified during World War I. Max Adler assumed a leftist position, Renner positioned himself on the right, and Bauer oscillated between the two wings depending on political struggles. ${ }^{27}$ These divisions did not affect their organisational ties. All Austromarxists supported the idea of party unity that Bauer had inherited from Victor Adler.

The integral component of the preservation of the multinational state, had already become manifest in Bauer's early articles and treatises. As is evident in his letter to Kautsky of June 1904, he dedicated himself to the study of economic history and economic crises, questions on tariff protection, and colonial policy at the age of 23. The results were published in the form of nine texts in Die Neue Zeit. His article, 'Marx' Theorien der Wirtschaftskrise' ('Marx's Theories of Economic Crisis'), in which he defended Marx's theory of value against the polemics of the Austrian School of Economics, was strongly approved of by Kautsky. Before the age of 24, Bauer had already earned a reputation as an outstanding speaker and teacher in self-education courses. ${ }^{28}$

In the memoirs of his colleagues, the young Bauer is described as a rationalist who understood reality in theoretical terms, but also as a romantic who was emotionally committed to the economic, social, and intellectual liberation of the proletariat. This conflicting nature would later be reiterated to explain the lifelong contradiction between his thoughts and practice. Even during the early days, Bauer attracted the attention of scientists who had few sympath-

26 See Bauer 1961.

27 Trotsky unfairly dismissed Adler's left position as 'literary opposition'. Adler was primarily a man of theory rather than practice. He was one of a few to come out in opposition to revisionism as early as the 1901 party congress in Vienna. He foresaw revisionism's deleterious effects for the workers' movement, such as its 'growing into' the political and legal structures of bourgeois society. Compare Löw, Mattl and Pfabigan 1986, p. 66.

28 He was often referred to as Victor Adler's 'prodigy' and 'great discovery'. 'When I joined the socialist movement in the autumn of 1905', wrote Julius Braunthal, 'Otto Bauer's reputation as its most erudite and sharp thinker was already established. He was 24 years old at the time' (our translation). Braunthal 1964, p. 79. 
ies for Social Democracy. Some of them, such as the anti-Marxist Ludwig von Mises, predicted a political future for him. ${ }^{29}$ Sigmund Freud, whom Bauer knew personally, did not agree with this flattering prophecy: he viewed him as a scientist and advised him against taking up politics altogether. ${ }^{30}$ Yet Bauer did not merely want to be a theorist and analyst. He considered it his duty to transform social reality, not just interpret it. His main reasons for championing socialism were axiological rather than economic or social. For him, socialism embraced the prospect of a moral and intellectual rebirth of individuals and societies. In his first major essays, he remained faithful to this moralistic perspective: In 'Marxismus und Ethik' ('Marxism and Ethics', 1906) and 'Geschichte eines Buches' ('History of a Book', 1907), which contained his commentary on Marx's Capital, he defended the evaluative orientation of socialism. For Bauer, socialism was principally an ethical goal, a form of social coexistence that would allow for the full realisation of all major human values. He held on to this until the end of his life, regarding it as his obligation to provide a basis for how this ideal, which he approached from a Kantian perspective, could be integrated into Marx's laws of social development. In the aforementioned works, he attempted to provide a foundation for socialism that was reliant on the premises of Kantian ethics. He overcame his propensity for Kantianism between 1916 and 1920, yet he continued to perceive universal moral rights as the roots of democratic ideals and humanist values. His writing, which he continued even in times of political failure and after his party was defeated, was imbued with social optimism. This was manifest in his unswerving faith in the continuity and linearity of social progress and his belief in the victory of socialism.

Bauer joined the SDAP when he began his studies in the winter semester of 1900-1. At the time, the unresolved nationalities question was the central problem in Austrian Social-Democratic politics. Nationalities conflicts, Czech separatism in particular, led to the intensification of German nationalism, but also restrained economic development within the empire and caused serious disruptions to parliamentary life. Indeed, the Hainfeld programme of 1889 entirely ignored the nationalities question, advocating instead the general principles of internationalism and the abolition of national privileges. Bauer dismissed this as a 'naive cosmopolitanism' ${ }^{31}$ Victor Adler eschewed the national question at party congresses, as he feared a surge in Slavic nationalist sentiments and a

29 As to Ludwig von Mises's characterisation of Bauer, compare Mozetič 1987, p. 7 .

$30 \quad$ See Singer 1979, p. 106.

31 Bauer 1996, p. 417. 
consequent disintegration of the party. His was a far-sighted politics: the federal party structure, enforced in 1897 by strong centres of opposition especially in Czechia and Poland, weakened the stability of the workers' movement. The party leadership held the view that the preservation of vast economic territories was in the interest of the proletariat. Hence, leaving aside the class aspect of the national question, the programme it adopted in Bern in 1899 demanded the transformation of Austria-Hungary into a federal state of autonomous peoples, defended the inviolability of the borders of the monarchy, and de facto rejected the right of nations to self-determination. This programme soon found theoretical support in Renner's 1902 concept of exterritorial nationalcultural autonomy. ${ }^{32}$ Bauer addressed this concept in several articles in Der Kampf in 1907-8 - 'Die soziale Gliederung der österreichischen Nationen' ('The Social Structure of the Austrian Nations'), 'Unser Nationalitätenprogramm und unsere Taktik' ('Our Nationalities Programme and Tactics'), and 'Massenpsyche und Sprachenrecht' ('Mass Psychology and Linguistic Right') - and in his most substantial work, The Question of Nationalities and Social Democracy, which Victor Adler had encouraged him to write. When the latter text was first published in 1907 in the second volume of Marx-Studien, it earned the 26-year-old author deserved fame and international recognition. ${ }^{33}$ Based on the reception of Karl Lamprecht's Die deutsche Geschichte (German History), ${ }^{34}$ Bauer's text was a departure from the widespread belief among Social Democrats (such as Jean Guesde and Rosa Luxemburg) that the national idea was but a bourgeois prejudice. What is more, it attacked canonical sociological theories by Ferdinand Tönnies, Georg Simmel, and Rudolf Stammler, and challenged the Social Darwinists. One of Bauer's achievements was that he applied Marx's method of historical and economic analysis - he was unjustly accused of having borrowed the form of presentation from Marx's The Eighteenth Brumaire of Louis Napo-

32 See Renner 1902.

33 This work was translated into many languages. Parts of it were published in Polish in 1908, enticing great interest from theorists in the Polish Socialist Party (PPS). In the 1920s, the programme of national-cultural autonomy inspired Kazimierz Domosławski, Zygmunt Dreszer, and Tadeusz Hołówko, while the Austrian idea of federalisation found the support of Bolesław Limanowski and Mieczysław Niedziałkowski. Leon Wasilewski maintained the idea of national assimilation. Echoes of the cultural interpretation of the nation contained in The Nationalities Question and Social Democracy can be found in the work of Tadeusz Rechlewski, Bronisław Siwik, M. Niedziałkowski and L. Wasilewski. I wrote on the differences between Austrian and Polish socialist conceptions in Czerwińska 1991, pp. 437-59.

Bauer wrote its sections as part of a dissertation in 1905 and added further parts in 1906. 
leon - to explain processes of nation forming, the causes of nationalities conflicts, and the important role of national interests in the life of modern societies.

Even though he was overburdened with teaching and publishing work, Bauer finished his studies with outstanding results. In 1906, he received the doctorate in canon from Vienna University. ${ }^{35}$ During this period, Bauer met Helena Gumplowicz-Landau at a meeting at the Café Central. She was married to a lawyer, Max Landau, and was 10 years older than Bauer. ${ }^{36}$ By that time, she had already authored many treatises in economic sciences and was an influential activist in the Polish Social Democratic Party of Galicia, a territorial organisation of the SDAP. Her open but critical mind and vivid temperament put a spell on Bauer - he married her in $1920 .{ }^{37}$ The couple had no children, but their choice turned out to be right for both: in spite of Bauer's affairs, she remained his closest partner in intellectual work and party activism until the end of his life. ${ }^{38}$

In 1907 , the government decided on a new electoral procedure, fearing that Austria had the potential to see a revolutionary uprising comparable to the 1905 disturbances in Russia. Following this, the first democratic parliamentary elections were held in May 1907. The result was a significant electoral success for the Social Democrats: their mandates went up from 10 (1901) to 87,

35 In the Polish and German editions of this book, I erroneously stated that he graduated 'sub auspiciis Imperatoris' (under the eye of the Emperor of Austria) - the highest possible honour for achievement in Austria at the time. Erich Hanisch corrected this in his Otto Bauer biography, writing that Bauer received the mark 'excellent' in two PhD exams, and 'satisfactory' in a third. In order to graduate 'sub auspiciis Imperiatoris', it was necessary to receive 'excellent' marks in all three exams. See Hanisch 2011, p. 72.

36 See Singer 1979, p. 112. Helene came from Krakow, studied economic sciences in Vienna and Zurich, and graduated with a PhD. When she met Bauer, she already had three children.

37 I am taking the opportunity to correct the year of the wedding, which I previously stated as 1914 in the Polish and German editions of this work. My mistake, also made by many others, resulted from a fact explained by Hanisch: they moved in together in an apartment in Kasernengasse 2/3/13 (known as Otto-Bauer-Gasse today), and lived there as an unmarried couple until 1920. Helena was only divorced in 1918. See Hanisch 2011, pp. 35-6.

38 As Hanisch states, the 45 -year-old Bauer fell in love with a very attractive Jewish woman named Hilde Marmorek (born Hofmann) in the mid 1920s. She was 11 years younger than he, and he kept the affair secret for a long time. It was revealed when Mr and Ms Marmorek headed to Bern at the same time as him in 1934. After her husband's death in the United States in 1943, Hilde married the well-known Social-Democratic journalist Jacques Hannak in 1945. In 1948, she returned to Vienna by Hannak's side. See Hanisch 2011, pp. 38-9. 
meaning that they became the strongest political group in parliament, and they remained so until 1912. The parliamentary group of the Social Democrats consisted of four fractions: German, Czech, Polish and Italian, as well as two Slovenian and Ukrainian representatives. Hence, there was a pressing need for a secretariat to coordinate all the work and ensure that the different national fractions advocated a common standpoint in parliament. In a move designed to demonstrate his recognition of Bauer's contribution to Social-Democratic theory, Victor Adler suggested that the 26-year-old take up the post of secretary of the parliamentary group. He held this function until the outbreak of World War I. As parliamentary group secretary, Bauer was the initiator of the Bodenbach party school founded in 1910. In addition to his work in parliament, he engaged in plenty of party activism. From 1911-33, he attended all party congresses, from 11 November 1911, he was a member of the SDAP leadership, and in 1914 he commenced his activity on the platforms of the Second International. In 1918, he became the parliamentary representative for the Social Democrats. During the second legislative period $(1923-5)$, he was a member of about 30 committees. Among other functions, he was the chair of the constitution committee and foreign policy committee, and a member of the central, finance, legal, trade and military committees. From 1919-33, he held more than 130 speeches in parliament, speaking with a passion that lent his words great suggestive power. In his presentations on 'Lebensmittelteuerung und Wohnungsnot' ('Rising Food Prices and Housing Shortage', 1911) and 'Wirtschaftskrise und Arbeitslosigkeit' ('Economic Crisis and Unemployment', 1913), he decried the deficiencies of a social security system that led to economic stagnation, low efficiency in production, especially in agriculture, a housing shortage, and growing unemployment. It is not difficult to understand why Bauer's appearances provoked indignation and turmoil in the ranks of the parliamentary right, as well as earning him the resentment of representatives of the aristocracy and bourgeois-peasant parties (the Christian Socials and Greater Germans).

Bauer combined his activity in parliament and party duties with his journalistic and publishing work. In 1907, he co-founded the central theoretical organ of the SDAP with Renner and Adolf Braun. The monthly journal, Der Kampf, was dedicated to the theory and immediate issues of the Austrian workers' movement. ${ }^{39}$ The journal gave him the opportunity to publish 152 theoretical articles under the monikers Karl Mann, Heinrich Weber, as well as his own name. From

39 Compare Bauer 1961, p. 14. The first issue of the journal was published in September 1907, after which monthly editions continued until 1934. When the party was banned, Bauer relaunched the journal in Berne. After his emigration to Paris in 1938, the journal continued to be published as Der sozialistische Kampf right up until Bauer's death. 
1911-34, he was also editor-in-chief for a socialist daily paper, the already established Arbeiter-Zeitung, initially just of the trade union section but later also the politics pages. ${ }^{40} \mathrm{His}$ colleagues fondly remembered the atmosphere of integrity and responsibility that Bauer created. He was wont to appear at the editorial office after midnight to discuss the contents of the upcoming edition with Friedrich Austerlitz. His friendliness towards all colleagues and tireless enthusiasm earned him respect. Upon leaving the editorial office, he normally wrote an article for the next edition at home before going to bed. ${ }^{41}$ Each of his texts was a spirited reaction to the matters of the workers' movement or the situation at home and abroad. Bauer commented on the aspirations, tasks, and tactics of the party, social and political events, the economic situation and foreign policy; he polemicised against the opponents of Social Democracy. The Arbeiter-Zeitung exerted tremendous influence when it came to forming and raising Austrian working-class consciousness.

In the period leading up the outbreak of World War I, tense relations between Austria and Serbia, as well as the threat posed by Tsarist Russia, became increasingly frequent topics of discussion at leadership conventions. The main questions were: how should the workers' party respond if tensions escalated, and would it be possible to exploit the war situation to commence revolutionary action? Victor Adler, who had always been negatively inclined towards strikes and revolutionary insurrection, admitted that the party had not discerned any programme of war prevention and felt entirely at the mercy of the political goals of world imperialism. The question of armed proletarian struggle to achieve socialism was, as it were, a marginal one. Despite its revolutionary rhetoric, the party leadership felt that Austria-Hungary could be transformed into a bourgeois-democratic, multinational state, and it should not exceed this expectation. Using the national movements to stage an insurrection against the ruling classes was therefore out of the question. The Social Democrats, including Bauer, supported the Austrian-German alliance because they feared an expansion of imperial Russia. They did not foresee the fatal consequences it would have for Austria-Hungary: the power of the state was reinforced, and the Germans insisted on intervening in the Balkans conflict by military means. In contrast to the German Social Democrats, the dissolution of parliament prevented the Austrian Social Democrats from declaring a firm position with respect to the international conflict. However, news articles from this period

\footnotetext{
$40 \quad$ See Singer 1979, p. 113.

41 During this period, Bauer was additionally burdened for family reasons. His mother died in 1913, and the health condition of his father, who he was looking after, worsened.
} 
prove that they endorsed the government's military measures. ${ }^{42}$ Bauer did not share Victor Adler's attitude to the war, nor did he agree with his pessimistic assessment of the strength of the Austrian workers' movement. He agreed with the German and Austrian Social Democrats, however, that the working class of a beleaguered country had the right of self-defence, even if it countered its class interests. ${ }^{43}$ This perspective was dominant among the activists of the Second International - Jean Jaurès, Édouard Vaillant and Georgi Plekhanov all took similar positions. Lenin, Rosa Luxemburg, Karl Liebknecht and other left participants who argued for instrumentalisation of the war to transform the state order were a distinct minority. The conflict in the Balkans plainly demonstrated for Bauer that imperialist aims and conflicting interests of Austria and Russia would lead to a war that would alter the borders of Europe and undermine the foundations of the Austro-Hungarian empire. His letter to Kautsky is evidence that he did not believe the war could be stopped by initiating a revolution. ${ }^{44}$

A few days after the outbreak of war, Bauer was drafted to the Galician front as lieutenant and soon became company commander. He participated in Austria-Hungary's victorious battles of Komarów, Rava-Ruska, and Przemyśl. ${ }^{45}$ The letters he sent to his party comrade, Karl Seitz, and his then-partner, Helene, in the period from 27 August-23 September 1914, testify to his courage and fighting spirit. However, they were also an attempt to absolve himself of guilt for participating in the imperialist war that he had earlier described as a threat to the development of the international workers' movement, and initiated by the interests of big capital. ${ }^{46}$ Bauer felt justified, as he now thought the war against imperial Russia, the bulwark of reaction in Europe, was in the interest of the entire working class and would accelerate its liberation. During the battle on the fringes of Krakow, where the Austrians had retreated from Russian attacks, Bauer became a Russian prisoner-of-war. ${ }^{47}$ He spent almost

42 See Austerlitz 1914 and 1914b.

43 Consequently, Hindel's claim that Bauer opposed the party's policy of 'homeland defence' is unjustified. See Hindel 1981, p. 13. During this period, Bauer did not join Friedrich Adler's left wing of the party, which in a letter of 7 August 1914 regarded the defence theory as a war objective of the Social Democrats.

Letter from Otto Bauer to Karl Kautsky, 3 January 1913.

45 The exact dates of these battles can be found in Botz 1978, p. 32.

46 See Singer 1979, p. 104.

47 See Bauer 1980v, pp. 1035-6. On 22 November, Bauer received orders to hold the line at all costs. During the Russian attack on the evening of the next day, he remained with only four other soldiers while the rest deserted. His conduct on the front was rewarded with 
three years in captivity in the Pow camp of Berezovka-Troitskosavsk (renamed Kyakhta after 1935) at the Mongolian border. He found his captivity hard to endure. This much is evident from his letters, which betray his longing for party comrades, feelings of isolation, and desperation for information about current affairs. Bauer dedicated his free time to honing his language skills he learned Russian, among other languages, but also studied mathematics. As a Pow, he wrote his only comprehensive philosophical treatise, Das Weltbild des Kapitalismus (The Worldview of Capitalism). Taking Kantianism to task, the text explained the historical origins and development of modern philosophical ideas from a Marxist point of view. After the outbreak of the Russian Revolution, Bauer was free to leave the Pow camp due to the efforts of Victor Adler and intervention by Hjalmar Branting, chair of the Scandinavian committee of the Socialist International. ${ }^{48}$ Instead of returning to Vienna, however, he was resettled to Petrograd, where he spent four weeks. ${ }^{49}$ During this time, he drew closer to the Mensheviks, which had an impact on his later analyses and perspectives for the development of Russia, his attitude to the dictatorship of the proletariat, and his concept of the mass party. He also followed the Bolsheviks with great attention and attended the meetings of workers' and soldiers' councils. In his 1917-18 correspondence with Kautsky, his change in perspective on the October Revolution and proletarian dictatorship was noticeable. Highlighting the momentousness of the social and political transformations in Soviet Russia, he distanced himself from Kautsky's charges against the Bolsheviks, later summarised by Kautsky in Dictatorship of the Proletariat (1918) and Marxism and Bolshevism:Democracy and Dictatorship (1918). ${ }^{50}$ For instance, Kautsky criticised the Bolsheviks for building socialism in an economically and culturally backward country while restricting political rights and liberties. ${ }^{51}$ How greatly the October Revolution had impressed Bauer was also evident in the

the Military Service Cross, Third Class. For more about Bauer's conduct in combat and attitude to war, see Botz 1978, p. 32, compare Hanisch 2011, pp. 80-6.

48 Letter from Victor Adler to Hjalmar Branting, 7 May 1917, quoted after Botz 1978, p. 34, compare Singer 1979, p. 113 .

49 According to Löw, Bauer was at all times a prisoner, yet he was granted permission to visit the library and study. He was also allowed to go to town when accompanied by a detective. He moved in with a Polish socialist, Peter Lapiński, who was a follower of Martov. Furthermore, he met Martov himself and visited his family, his sister Lydia, and her husband Bogdan almost every day, looking after their daughter, who was ill with tuberculosis, with great self-sacrifice. See Löw 1980, p. 10; compare Leichter 1970, p. 311.

$50 \quad$ See Bauer 1980l, p. 1040; Bauer 1980m, p. 1044; Bauer 1979l, p. 549.

$5^{1}$ Lydia Dan successfully beseeched the war minister, Boris Savinkov. In September 1917, Bauer was classed as a war cripple and designated for a prisoner exchange - see Löw 1980, 
first article he wrote upon his return to Austria on 10 October 1917: 'Die Russische Revolution und das Europäische Proletariat' ('The Russian Revolution and the European Proletariat') reflected on the course and meaning of the revolution.

Upon returning to Vienna, Bauer resumed party activity. His stay in Russia had radicalised his political views. He changed his evaluation of the war and adjusted his perspective on the role of the workers' party in the capitalist state. Concurrently, he mitigated his stance on the dictatorship of the proletariat. It was also at this time that he no longer hoped that the Austro-Hungarian Empire would be salvaged. He now expected its demise, the emergence of new states in Europe, and the potential eruption of a proletarian revolution in Austria. A cycle of articles in Der Kampf expressed these sentiments. ${ }^{52}$ His positions prompted strong objections from Renner - it was the first time their friendship was in jeopardy. In his wartime works, Österreichs Erneuerung (Austria's Renewal, 1916) and Marxismus, Krieg und Internationale (Marxism, War and the International, 1917), Renner sought to prove the necessity in preserving vast economic territories and cast doubt on the possibility of an autonomous existence for the states of Austria-Hungary. He argued that the German-Austrian working class should resist potential Slavic revolutions to defend its own economic and political interests. In 1917, Bauer joined the left wing of the party, which had vigorously reprimanded the pro-war dispositions of the party right. His critique had no influence upon the policies of the SDAP and the government. Later, the so-called 'Declaration of the Left' was drafted under Bauer's authority. ${ }^{53} \mathrm{~A}$ programme that denounced the politics of compromise with bourgeois parties, it urged the party leadership to ardently work to end the war. The introduction of the programme assured its readers that the left did not wish to jeopardise the unity of the party, but hoped to make it more democratic and ideologically tolerant. The programme was more of a wish list than a real proposal for an alternative politics.

Several factors provided a fertile breeding ground for increased anti-war sentiments in Austria-Hungary: the prolonged war, the defeat of the AustroHungarian army on the front, news about the outbreak of revolution in Russia passed on by soldiers, and a poor supply of food and medication in the crown lands. This mood was apparent at the Vienna workers' anti-war demonstration

p. 11. Victor Adler welcomed him back with great joy. It was at the time he saw Bauer as his successor. See letter from Victor Adler to Karl Kautsky, 14 November 1917.

$5^{2}$ See Bauer 1918.

53 At the time, Friedrich Adler was in prison for his assassination of Prime Minister Karl von Stürgkh. 
on 28 November 1916, Friedrich Adler's assassination of Prime Minister Karl Stürgkh on 21 October 1916, and the strike in January 1918. In the crown countries, which had recognised the rule of the Habsburgs at the outbreak of the war, separatist movements, such as the Polish separatist movement and the Czech movement under the leadership of Tomás Masaryk, rose to the surface. As far as outside political observers were concerned, the days of the dynasty were soon to come to an end. Only two forces did not accept the historical inevitability of the monarchy's demise: the government and the right wing of the Social Democrats, which constituted the majority of the party. Ernest von Koerber's government introduced a programme for the autonomy of AustroHungarian countries, and, prior to that, passed an act that allowed Galicia to separate. These solutions were too little, too late. There were no parties left that might have been interested in them. The same fate was bestowed on Charles I of Austria's manifesto of 17 October 1918, by virtue of which all nations of the monarchy were to be granted extensive autonomy. Karl Renner's 'Mitteleuropa' ('central Europe') project, which had been an official objective of Social-Democratic politics since 1916, was based on similar premises. The goal was to build a league of nations from the North Sea to the Aegean Sea. A democratic constitution would guarantee equal economic and cultural development for all member states. Bauer's left minority viewed this project sceptically, introducing in 1917 a programme which guaranteed the right of nations to self-determination. This programme was more concerned with the German minority in Austria than it was with Slavic states. From October to November 1918, independent governments emerged in Czechoslovakia, Poland and Hungary, and with Charles I's resignation on 11 November 1918, the existence of the monarchy was brought to an end. The most obvious reasons for its demise were wartime defeats and national liberation efforts, though there were further contributing factors under the meniscus: the bureaucratised mechanism of power in the constitutional monarchy, which only functioned by virtue of the law of inertia, miscalculations in foreign policy, the military shortcomings of the army, the elderly form of Emperor Franz Joseph I. Furthermore, parliamentarism was still weak in Austria.

As the empire was in its death throes, German-speaking delegates of the strongest political parties - the Christian Social Party, the Greater German People's Party, and the SDAP - convened the Provisional National Assembly and founded the first coalition government, the State Council, on 21 November 1918. This was done in order to curb riots on the part of workers, who demanded the establishment of a democratic state power, an end to the war, and the eradication of restrictions in the factories. However, the individual parties had opposing interests that could not be brought into accord. The liberal 
politician, Josef Redlich, wrote: 'Adler demands the republic, the Christian Socials demand the monarchy, and the Greater Germans demand annexation to the German Reich' (our translation). ${ }^{54}$ During the first cabinet meeting, Victor Adler maintained that the coalition was a historical necessity, and that parliament had to be recognised as an instrument of struggle for power and socialism. Moreover, he voiced anxiety about the fate of the German nation in Austria, claiming that it would face annexation by Germany if it did not found its own state as soon as possible. His fear at the time was unjustified. The German Reich, after all, faced the same fate as the Habsburg Empire, with revolutionary uprisings spreading over Germany. Nonetheless, his fear possibly reflected the vivid aversion of the working class towards Prussian Germany. On 12 November 1918, the Provisional National Assembly decided upon a constitution in which German Austria was declared a constituent part of the German Republic. The purpose of this was to prevent a further escalation of workers' demonstrations. ${ }^{55}$ The constitutional decision to grant popular determination of public rights, however, did not settle the question of state order, the extent of mass participation in state power, and the role of the workers', peasants' and soldiers' councils that had existed since 1917. On the day before the proclamation of the republic, Victor Adler died, leaving his legacy to Bauer. From that moment, Bauer was the factual, if not formal, leader of the SDAP. He also assumed the leadership of the parliamentary fraction and took over Adler's role as chair of the foreign ministry. Additionally, he became the chair of the socialisation committee in March 1919.

Bauer became the de facto leader of the party at a time when its entire political line to date, as well as the politics of Austromarxism at large, was put to

54 'Adler verlangt die Republik, die Christlichsozialen die Monarchie, die Deutsch-Nationalen den Anschluss an das Deutsche Reich' - Weinzierl 1982, p. 12. The coalition divided responsibilities among parties according to geographical locations: the Social Democrats maintained their influence in the cities, while the Christian Social Party focused on maintaining theirs in the countryside. One consequence of this division of labour was that circa 500,000 members of the rural proletariat remained out of reach for the SDAP and were not taken into consideration when it came to social legislation. This strengthened the bourgeoisie in the countryside.

55 The Communist Party of Austria (КРӧ) - a party that emerged out of the Left Radicals around Paul and Elfriede Friedländer, Russian prisoners of war, and radical youths attempted to seize the moment during the proclamation of the republic and win over the protesting workers to the idea of establishing a soviet republic. However, it was too weak organisationally, numerically, and politically. Its long-time party leader, Johann Koplenig, in Koplenig 1963, p. 118, confirms this. The KPÖ was not represented in the National Assembly or in the regional assemblies, the Landtage. 
the test. In the autumn of 1918, Austria, particularly Vienna, was gripped by a revolutionary wave. The situation was contradictory: radical splinter groups of the working class urged the party leadership to take power and introduce the dictatorship of the proletariat. Meanwhile, the leaders of the SDAP, a party among whose ranks the necessity of revolutionary transformation had been repeatedly evoked since 1889 , assumed a critical distance to the events. In fact, they deployed all means at their disposal to prevent a proletarian revolution. While Victor Adler feared revolution despite considering its outbreak inevitable in 1918, Bauer and Friedrich Adler, who had educed the trust of the working class through reformist successes, actively attempted to convince the proletariat that revolution in Austria had no purpose and was doomed to fail. Bauer's standpoint was characterised by a strong pragmatic perspective that outweighed theoretical considerations. The political decision for the reformist path, for parliamentary democracy, and against a dictatorship of the proletariat was based on an actual estimation of the social balance of power. ${ }^{56}$ Vienna in particular was revolutionary, yet the rural provinces were under Christian Social influence and were hostile towards revolution, and the Communist Party of Austria and radical left groups were isolated. Unlike the Russian proletariat, who had nothing to lose when faced with an analogous situation, the majority of the Austrian working class did not want to jeopardise the gains of reformist policies. To assume that the Austrian workers would leave the revolutionary ranks when faced with difficult times was therefore justified.

The line of Bauer's foreign policies was wholly dominated by the desire to maintain the national unity of Germans in the face of social revolution (from 21 November 1918 until 26 July 1919, he was foreign secretary). During the peace negotiations of Saint-Germain in May 1919, the Austrian peace delegation led by Chancellor Renner bore witness to a disaster. The victorious powers found Austria-Hungary guilty of initiating the war, and as a result imposed war reparations, and drew new borders meaning the loss of territories in which Germans were the majority, such as Bohemia, Moravia, South Tyrol, and parts of Carinthia and Styria. During this arduous time, Bauer's primary objective was to regain these territories. In the Arbeiter-Zeitung, he protested against the decision to blame the new Austrian state for the foreign policies of the monarchy. ${ }^{57}$ However, he dedicated most of his attention to the question of an Austrian Anschluss to Germany, which had been ignored in the treaty. Bismarck's 'lesser German solution' of 1871, in which Austria had been excluded from

$56 \quad$ I will consider this more extensively in point 1.2 of Chapter 5 .

$57 \quad$ See Botz 1978, p. 32 . 
the empire, did not correspond with the preference of the German-speaking parts of Austria's population. The national consciousness of the society was torn. They were Austrians, yet they considered themselves German. This was accompanied by the notion that German culture was superior to other cultures within the empire. While nationalist tendencies and the demand for Anschluss were especially pronounced in the Greater German camp, they were far from unknown in the Christian Social Party and the SDAP. Victor Adler was among the advocates of unification, and Bauer continued the legacy in considering Anschluss the central question of his foreign policy. He envisioned the creation of a body of German states with centrally administered foreign and financial policies and continued autonomy in domestic questions. Bauer stressed three aspects of the Anschluss: national, economic, and political (revolutionary). The working class of Austria, which did not desire close links to Prussian Germany, was largely hostile to this idea. It had strong reservations about the SDAP's efforts for reunification, such as its official recognition of the request for Anschluss on 6 June 1917, and repeated appeals for Anschluss in the national programme of the left in January 1918. Bauer was fully aware of these sentiments, and he knew that the party leadership had misgivings about the unification question. What is more, he expected that the victorious countries would resist any such attempts. As early as October 1918, an active propaganda campaign in favour of Anschluss began. Bauer published a series of articles illustrating its historical necessity in the Arbeiter-Zeitung, attempting to seduce the workers as well as the party majority to his positions. As Viktor Reiman ironically commented, 'for the first and last time, his willingness to act was greater than his habit of cautiously evaluating all possibilities.' ${ }^{58}$ Yet Bauer's efforts failed. It is true that the 1 November 1918 plenum of the SDAP declared the Anschluss demand an official aim of the party, and Bauer's Berlin talks with the German Chancellor, Friedrich Ebert, culminated in a secret arrangement concerning Anschluss on 2 February 1919. However, these plans were never put into practice due to the opposition of the Entente powers. Of all countries, France protested most vehemently against the agreement, fearing a surge in German power and a potential reconstruction of the German super-state. Czechoslovakia also opposed the project. Equally remarkable is the fact that the Anschluss found no support from the German government, which in its political calculations considered the Austrian question of secondary importance. ${ }^{59}$ Consequently, the French Prime Minister, Georges Clémenceau, had no

$58 \quad$ Reimann 1968, p. 284.

59 Among those who spoke out against an Anschluss was also the Chancellor, Paul Hirsch, 
qualms enforcing a ban on Anschluss in the Treaty of Saint-Germain and erasing the word 'German' from the state name and constitution. Equally, Bauer's attempts to reclaim Austria's lost territories failed: South Tyrol; ${ }^{60}$ the whole of the crown land Craniola, a territory disputed by Yugoslavia; and territories inhabited by 3.5 million Sudeten Germans, which Czechoslovakia incorporated according to the Treaty of Saint-Germain. Austria's economic instability and political isolation in the early years of the republic, which allowed the victorious powers unlimited room for manoeuvre, validated the failure of Bauer's foreign policy. Austria suffered great territorial and diplomatic losses during Bauer's time in office as foreign secretary. Beside South Tyrol and the Germanspeaking territories of Czechoslovakia, South Carinthia and South Styria were also at stake. A plebiscite in Vorarlberg concerning union with Switzerland resulted in 80 percent of the votes cast against Austria, even if the annexation was not accomplished and the territory remained Austrian. In addition, relations with Germany and Italy were tense, and the tariffs union with Liechtenstein, which had been in place since $185^{2}$, was dissolved. ${ }^{61}$ Embittered by his political defeats, Bauer tendered his resignation to the chair of the National Assembly on 25 July 1919. He explained the motivation behind his decision in more detail in the pamphlet, Acht Monate auswärtiger Politik (Eight Months of Foreign Policy, 1919). ${ }^{62}$ The ratification of the contract of Saint-Germain, which extinguished any hope for unification with Germany, coincided with Bauer's resignation from government and election as chair of the SDAP parliamentary club.

On 16 February 1919, the first democratic National Assembly elections took place. Winning 72 seats, the Social Democrats saw a victory over the Christian Social Party (69 seats) and Greater German Party ( 26 seats). In the coalition government formed by the SDAP and the Christian Social Party on 15 March 1919,

who acted on behalf of the Prussian government. See letter from Ludo Hartmann to Otto Bauer, 24 June 1919; compare Reimann 1968, p. 284.

6o On 8 July 1919, Prince Borghese refused to participate in the negotiations on behalf of the Italian government.

61 When characterising Bauer in his role as state secretary for foreign affairs, Hanisch writes that Bauer was lacking diplomatic experience, knowledge of conventions, a sense of situation that characterised the aristocrats holding this office at the time, and, finally, the kind of presence that is useful in this position. See Hanisch 2011, pp. 149-50.

62 After Bauer's resignation, Karl Renner took over the Ministry of Foreign Affairs as its Chancellor. On 5 July 1920, he initiated an agreement with the Soviet Union together with the Christian Social Party in order to secure Austria's neutrality in the East-West conflict. Compare Haas 1982, p. 5 . 
the Social Democrats assumed three important areas of responsibility: Karl Renner became Chancellor, Otto Bauer became Foreign Minister, and Julius Deutsch became Defence Minister. In addition, the Social Democrats chaired most offices in Vienna - Karl Seitz, for instance, became mayor. Fearing that the revolutionary fervour might grow and a soviet republic be installed, as had just occurred in neighbouring Hungary and Bavaria in March and April respectively, the Social Democrats and Christian Socials made joint efforts to expand democracy, introduce social security legislation, and improve the living conditions of all working people. ${ }^{63}$ On 14 March 1919, the National Assembly formed a socialisation committee chaired by Bauer and the prelate Ignaz Seipel, who would later become one of Bauer's most loathed political opponents. Thereafter, Bauer established a socialisation programme. Its fundamental idea was the gradual socialisation of highly developed production branches, large estates, and forests and pasture land in return for an adequate compensation. ${ }^{64}$ The programme was so far from being radical that it even found the support of Seipel and bourgeois circles who hoped it would stifle the revolutionary mood of the working class. The bourgeois camp did not overestimate the implications of Bauer's demand to build industrial councils. It was aware that these would not shake the foundations of the capitalist economic structure. In the spring of 1919, parliament passed a range of socialisation laws, which largely continue to apply in Austria. High taxes imposed upon the wealthy were used for the development of social welfare, cultural and educational institutions, and housing. The socialists' local government policies, which benefited not only the working class, but also officials and parts of the peasantry, gained the workers' support. Given the situation of the working masses in the Hungarian and Bavarian republics, which had been crushed by counter-revolution,

63 Hans Hautmann offers useful information on social changes heralded by the bourgeois revolution. Among these were the 'dismissal and, finally, expulsion of the last monarch from the country, the dismissal of all members of the ruling dynasty by virtue of the Habsburg law of 3 April 1919, the abolition of all aristocratic privileges, the removal of the military caste and disappearance of the old imperial army, the dissolution of any bodies based on political privilege such as the House of Lords, the abolition of class and census suffrage in the regions and communes, and the restoration and expansion of civil liberties' (our translation). Hautmann 2007, p. 95 and p. 97.

64 In 1919, Bauer popularised this programme in a series of ten articles in the Arbeiter-Zeitung. They were republished as a collection entitled Der Weg zum Sozialismus (The Road to Socialism) in the same year. The fact that there was great interest in this programme across the Second International is evidenced by the fact that 12 editions were published within two years. Most of them were translated into different languages. 
they were justified in considering Bauer's politics of preventing revolution farsighted. The author of the socialisation programme himself was more sceptical in evaluating the chances of its fulfilment than the enthusiastic workers, who joined the party en masse (it had 500,000 members at the time). Bauer feared the economic weakness of the state and the consolidation of capitalist forces as threats to the endurance of his reforms. His fears would soon be confirmed: the emboldened position of the Christian Social Party in the countryside and the Social Democrats' concessions to capitalist circles meant that the socialisation question waned in practical importance after August 1919. Its political effects, however, met the expectations of the SDAP leadership: not only did it avert the danger of revolution, but it also increased the workers' trust and belief in the effectiveness of SDAP leadership policies. These circumstances affirmed Bauer in his belief that the peaceful, democratic, so-called 'third way' to socialism was an optimal solution under Austrian circumstances.

In fact, the political situation of 1919 revealed that the chosen strategy and tactics were based on a poor assessment of the actual situation. As early as 8 January 1919, the chief of police, Johann Schober, presented a list of key measures for the struggle against Bolshevism at a cabinet meeting. The SocialDemocratic politicians were not fully aware that the Christian Social Party's willingness to form a coalition government had sparked the revolutionary insurrection and shaken the socio-political foundations of the postwar period. After the fall of the Bavarian and Hungarian soviet republics on 2 May and 1 July 1919 respectively, the danger of revolution in Austria had already been contained. The bourgeois bloc in parliament gradually began to exclude the Social Democrats from government. The first step in this direction was made when a cabinet based on proportional representation replaced the coalition government. After an interpellation submitted by delegates of the Greater German Party on 10 June 1920, co-operation between the SDAP and the Christian Social Party in this cabinet was relinquished. The second step was made when the constitution drafted by Hans Kelsen was adopted on 1 November $1920 .{ }^{65}$ The Social-Democratic leaders, including Bauer, supported this draft because it legitimised the coalition between the SDAP and the Christian Socials. It would serve the Social Democrats as a platform for the co-operation between the working class and peasantry. The SDAP leadership was wrong to expect that the

65 Hans Kelsen (1881-1973) was an Austrian state and law theorist, the founder of legal normativism and the 'pure theory of law'. He drew on the normative method, a peculiar choice with regards to law, and assumed a dualism of being and ought. Consequently, any judgement in the realm of legal theory was abandoned, and law was abstracted from sociohistorical and psychological foundations. 
constitution would yield positive results for its strategic goals. The Austrian parliamentary tradition was very weak, and the system of social partnership still immature. In July 1920, Bauer anticipated an outbreak of social conflicts and optimistically hoped for a reinvigorated co-operation between the bourgeois bloc and the Social Democrats. He hoped that this would culminate in new socio-political reforms to the advantage of the industrial working class, which was a crude miscalculation. ${ }^{66}$ Because Lower Austria had been constitutionally targeted as an autonomous land, Social-Democratic influence was limited to the capital and Christian Social and Greater German influence was fortified in the provinces. At the July 1920 party congress, Bauer stated that Austria could not be a socialist oasis in capitalist Europe. This was a legitimate argument, yet it also demonstrated the vulnerability of the workers' party under changing socio-political circumstances.

The elections held on 17 October 1920 according to the new constitution, which the Christian Social Party won, validated the SDAP's impotence. No longer looking to compromise with the socialists, its leaders formed a cabinet of officials under the authority of Michael Mayr. ${ }^{67}$ In this situation, the Social Democrats had no choice but to join the opposition along with the Greater Germans, whose support the SDAP fought for in vain. The only common ground between these two parties was their agreement on the Anschluss question, which was now obsolete. The Greater Germans had a different electoral base the aristocracy, big capital, and part of the bourgeoisie - and cultivated a monarchist and nationalist orientation. During this period, Bauer did not doubt for a second that the chosen tactic was correct, that power could be recaptured, and that the parliamentary majority could be won. These prognoses were not entirely unsubstantiated: after the 1923 elections, when the Social Democrats increased their number of seats in parliament by six mandates, the party was but 300,000 votes short of exercising power on its own. However, the domestic situation made the realisation of Bauer's goal impossible. It was characterised by growing unemployment, hyperinflation, and increasing political apathy. Furthermore, society was increasingly polarised due to dispossession of parts of the petty bourgeoisie, which tilted the balance in favour of big capital. Conflicts between the paramilitary formations of different parties were not unusual.

66 See Bauer 1920.

67 In these elections, the Christian Socials won 79 mandates, the Social Democrats won 62, the Greater Germans 18, the Peasant Party 6, and independents 1 - see Zöllner 1979, p. 502 . 
After the SDAP had joined the opposition, three problems were decisive for Bauer as the principle architect of the party's theoretical and strategic line: (1) defending the economic and social interests of the working class during the period of crisis and hyperinflation; (2) winning the parliamentary majority by gaining influence in the countryside; and (3) building a platform on which all wings of the socialist movement could communicate. The third question was bound to the necessity of a theoretical perspective justifying the adoption of concepts that were, according to the theoretical tradition of the Second International, contradictory: democracy and dictatorship, peaceful and revolutionary ways to socialism. These were the questions with which Bauer and the SDAP were preoccupied from 1920-6.

The phenomena dissected by Bauer in his 1921 pamphlet, Volkswirtschaftliche Fragen (Questions of Political Economy) - progressive devalorisation of the crown since 1918, rising food prices (a threefold increase from July to October 1921), and unsuccessful attempts to get international credit - led to riots in Vienna from 1921-2 and witnessed the fall of two cabinets: Michael Mayr's on 21 June 1921 and Johann Schober's on 30 May 1922. The government crisis allowed the most intelligent adversary of Social Democracy, the prelate Ignaz Seipel, to come to power. ${ }^{68}$ Seipel was a prime example of the Christian-Social Party's 'Vienna trend'. His anti-democratic and pro-monarchy politics were driven by two interlinked objectives: to overcome the crisis in Austria, and to establish a strong bourgeois state without the parliamentary influence of Social Democracy. On 4 November 1922 in Geneva, Seipel effected a signed agreement between Austria and the governments of France, England, Italy and Czechoslovakia, by virtue of which Austria received 650,000 Krones in credit to save its economy. However, the agreement bore two adverse conditions for Austria. First, Austria would be banned from seeking Anschluss for the next 20 years. Second, state finances would be subject to the control of the commissary general of the Entente countries. The ratification of the Geneva protocols in parliament on 27 November 1922 garnered the Social Democrats' passionate resistance. As the conference in Geneva was in progress, Bauer made a presentation about Austria's political and economic situation, 'Der Genfer Knechtungsvertrag und die Sozialdemokratie' ('The Enslaving Contract of Geneva and Social Democracy') at the party congress on 14 October 1922. It contained a draft for a budget overhaul by means of so-called self-help, i.e. the voluntary self-taxation of the working class and bourgeoisie. It is not for nothing that this

68 Seipel had already entered the political stage during World War I, when he was a follower of Heinrich Lammasch. 
draft was seen as problematic. Bauer was accused of negligence of political conditions. The proletariat would not be able to bear a higher tax burden, and the bourgeoisie would certainly not voluntarily agree to it. At the party congress in June 1923, Bauer acknowledged that Social Democracy had not succeeded in convincing society to share the cost of overcoming the crisis. Nonetheless, the Social Democrats scored a partial victory in the struggle against the 'restructuring programme' of Geneva, whose consequences hit the working class and civil servants first and foremost. The controversial points of the programme were erased, and the positions of the party leadership resulted in an increase in votes by 23 percent in the 1923 elections (the Christian Social Party was one mandate short of absolute majority). ${ }^{69}$ As an aside, Seipel's policies, although they did not solve unemployment nor even temporarily benefit the poorer social classes, nevertheless stabilised the currency and spared the country from economic collapse.

The growing support of the electorate in the 1923 elections did not result in the victory of Social Democracy just yet. Only 68 socialists were granted seats in parliament, while the Christian Social Party was awarded 82. The SDAP leadership, proud of maintaining organisational unity and swelling party ranks, was convinced that their strategy would lead to winning the parliamentary majority and peaceful radical change in the forthcoming years. The actual political situation, however, was not that advantageous. Beside a strong bourgeois bloc and a decidedly right-wing government that had abolished all social and political revolutionary successes of the working class, tensions between the city and the countryside and a poor economic situation for workers prevailed. The middle class, which, due to Social-Democratic policies which aimed to benefit the petty bourgeoisie, had previously bolstered the ranks of the SDAP in 1919, changed sides and joined the Christian Social camp in the wake of inflation. The party's strategy was based on a misreading of the political situation. Bauer's stubborn adherence to his political strategy, which he could in no way implement, solidified the character of the SDAP leadership's policies and led to defeat.

Bauer created the main pillars of these politics based on his experiences in Russia and the revolutionary period in Austria. His writings from 1919-24 - such as Weltrevolution (World Revolution, 1919), Der Weg zum Sozialismus (The Path to Socialism, 1919), Bolschewismus oder Sozialdemokratie? (Bolshevism or Social

69 Löw has a different view on this, claiming that the Social Democrats relinquished the possibility of winning the middle classes by showing too much tolerance towards suggestions from the bourgeois camp. Compare Löw 1980, p. 32. 
Democracy, 1920) - attracted great interest abroad. Elaborating a so-called 'third way' to socialism, all of these works negated the Bolshevik revolutionary model, which Bauer rejected for theoretical, moral and tactical reasons. He envisioned a parliamentary democratic and social revolution, and hoped that the objective laws of capitalist development would lead to a transformation of capitalism into socialism. This would gradually lead to the domination and intellectual hegemony of the working class within the democratic state. In his texts, Bauer attached great importance to the qualitative differences between the conditions of struggle in Western democracies and those in semi-feudal Russia. In spite of the different positions of the Russian and Austrian peasantry, the experience of the Soviet revolution drew Bauer's attention to the alliance between workers and peasants. Since its inception, Social Democracy had attempted to secure the support of the working class in the big industrial and commercial territories, leaving the peasantry to the influence of the Christian Socials. Consequently, it did not have any agrarian programme, and policies concerning the confiscation of large estates did not elicit the interest of Austrian peasants. After all, they were large estate holders by virtue of the 1848 law, and unlike the Russian peasants, they did not yearn for land. Hence, the Social Democrats had little chance of overcoming the distrust of the clerical peasantry. For them, the only possibility was to win the agrarian proletariat. In order to achieve this, the SDAP needed a reform programme that could acquire tangible economic and social gains. The SDAP's lack of faith in the possibility and endurance of a worker-peasant alliance was a further disadvantage for Social Democracy. While Bauer was also sceptical about such an alliance, he recognised the necessity of looking into the agrarian question in view of the upcoming elections. In 1921, he published 'Leitsätze zur Agrarpolitik' ('Principles of Agrarian Policy') in Der Kampf, which contained the foundations for a discussion in the SDAP. In 1924, he summoned the convention of the agrarian committee, which was to design a complex agrarian programme (it was only published in 1926). With reference to collections of legal acts, he prepared a comprehensive sociological and historical study of the Austrian agrarian structure: Der Kampf um Wald und Weide (The Struggle for Forests and Pastures, 1925). Aside from comprising a history of the distribution of land, usage rights of forests and pastures in Austria, and the independence struggle of Austrian peasants - held in high esteem by experts - it contained the agrarian programme of Social Democracy. The two basic premises of this programme were thus: stages between different economic formations last a very long time, and capitalist and socialist elements coexist in agriculture. This was not an attractive programme for people in the countryside: it did not promise anything more to land-owning peasants than what they had already received in the past, which 
was the socialisation of large estates and the right to preserve their exclusive property. Nor did it have anything to offer the rural poor, since it did not provide any social welfare legislation similar to that enjoyed by the working class. It is therefore unsurprising that Bauer's attempt to engage with the peasantry was ultimately unsuccessful.

In the years 1921-6, Bauer enthusiastically joined Friedrich Adler, the delegates of the British Independent Labour Party (ILP) and the Independent Social Democratic Party of Germany (USPD) in their efforts to facilitate a rapprochement of the centrist Social-Democratic parties that had drifted apart after 1918. Together with Friedrich Adler, he attempted to rebuild the International. One expression of this aspiration towards unity was the founding of the International Working Union of Socialist Parties, the so-called Vienna International, at the Vienna convention from 22-7 February 1921. Because its ideological orientation lay somewhere between the Socialist and Communist internationals, the organisation, which united 20 parties from 13 countries, was also known as the $2^{1 / 2}$ International. Bauer's voice was decisive in determining its programmatic line. The main statements focused on the struggle against imperialism and counter-revolution, the two-stage revolution as outlined by the Austromarxist doctrine (the political revolution first, then gradually the economic and social revolutions), and the establishment of diplomatic and economic ties with Soviet Russia. At the time, Bauer was convinced that the mutually opposing methods of Social Democrats and Communists could somehow be reconciled with the common interest of the international workers' movement. He believed that a common theoretical approach to the class struggle could be drafted. This turned out to be impossible, as the rift within the international workers' movement deepened even further. The lifespan of the Vienna International was a mere two years, its demise coinciding with the dissolution of the USPD and the defeat of the ILP. The relative insignificance of its successes testified to the weakness of centrist and leftist tendencies in Social Democracy. Bauer, still dedicated to the idea of unification, initiated a convention of the executives of all three internationals in Berlin from 2-5 April 1922 - yet the meeting did not result in an agreement. He was an active participant in the founding congress of the Labour and Socialist International (LSI), in Hamburg from 21-25 May 1923, where he gave a programmatic talk - Bauer belonged to the bureau and executive of the LSI. In his presentation, he made it clear that he preferred the free play of forces and parliamentary means of class struggle, pleading for the gradual realisation of socialism under the conditions of a bourgeois-democratic republic.

The real political muscle of the SDAP was systematically weakened when the party joined the opposition upon Bauer's advice in 1920. In turn, the power 
structures of the Christian Social and Greater German coalition were consolidated and enlarged. By and by, the coalition abolished democracy and worked towards the establishment of an autocratic state. Bauer, Braunthal and Seitz evidently misjudged the direction in which state policies were heading. The party leadership nursed the illusion that every increase in mandates meant that the working class would soon inevitably seize power; despite the fact that the economic and political situation of the proletariat had worsened every year from $1921-5$, while the offensive of the domestic enemies of democracy grew stronger. ${ }^{70}$

The new economic and social conditions forced the SDAP leadership to revise its programme, which had been untouched since the Vienna party congress of 1901. Significant changes were undertaken at the party congress in Linz from 30 October-2 November 1926. The tactical groundwork was laid for the party to continue operating under conditions of the counter-revolutionary and fascist advance. This basis was only established through fierce argument, exposing the brittle tensions of party leaders who had been so carefully maintaining a united front to the working class. As it now emerged, party unity had been but a myth - a myth that Bauer himself firmly believed in at the time. The cause for the argument between the party right, left, and centre was a divergence of opinion as to whether Marx's theses and prognoses still applied in changed economic and political circumstances. To be precise, the question was how much of his revolutionary doctrine could be preserved in view of the reformist practice. Bauer's position at the party congress in Linz was a difficult one. He wanted to prevent a split in the party at all costs. Hence, when the right wing around Renner wanted to erase the demand for a dictatorship of the proletariat from the programme, while the left around Max Adler wished to preserve it, Bauer suggested a compromise. It received the majority of votes at the congress. The motion contained the concept of 'defensive violence', which permitted the working class to use force only if the bourgeois parties strayed from the democratic path. ${ }^{71}$ Ignoring the creeping decline of democracy in Austria, which had been an ongoing process since the early 1920s, the draft declared it the vital condition for social upheaval. Certainly, this decision came a few years too late and could not achieve a serious change of SDAP policies. Even if the party leadership was not fully aware of it, this was mainly because the integration of reformism into the organs of the state had progressed to such a

70 During these years, the unemployment rate rose fivefold. Meanwhile, real income decreased by 25 percent, and social welfare for workers was reduced.

71 See Berchtold 1967, p. 253. 
degree that the Social Democrats were unable to tackle even obvious symptoms of democracy's degeneration. One such problem was the armed paramilitary units deployed by the bourgeois parties, especially the wave of terror unleashed by the Heimwehr (Home Guard) after 1923, which grew more severe after 1925. The head of government, Ignaz Seipel, deemed the debate of Linz to be another political manoeuvre rather than a genuine threat. Nonetheless, Bauer had more in mind than mere tactics when establishing the 'theory of defensive violence' he intended to bridge the gap between reformism and revolutionary socialism. While he already entertained the idea at that time, he would go on to elaborate it theoretically in his last book, Zwischen zwei Weltkriegen (Between Two World Wars), thus establishing integral socialism, a theory now associated with his name.

In light of the enthusiasm and faith expressed in Linz, the Austrian working class once again provided its trust, despite suffering from mass unemployment (in 1927, the unemployment rate in Vienna was 33 percent higher than in 1923 and 116 percent higher outside of Vienna), a lack of compliance with social legislation in the factories, and power abuses on the part of officials and police. ${ }^{72}$ Its faith was beneficial for the SDAP, which won its all-time largest share of the vote at 42 percent in the 24 April 1927 elections. This was also due to the party's electoral agitation, which focused on the protection of rent controls. Although the elections meant three additional seats for the Social Democrats (71 mandates in total) and a bitter defeat for the Christian Social Party (which lost nine mandates), this did not change the dynamics in parliament. ${ }^{73}$ The lone Social Democrats faced the united opposition of conservative forces: the Christian Socials, the Greater Germans, the Rural Federation supported by the army under the leadership of Carl Vaugoin, and loose paramilitary organisations such as the Heimwehr and the Frontkämpfervereinigung (Front Fighters' Union). The Social Democrats were only able to counter the military organisations of the bourgeois bloc with the poorly armed Republikanischer Schutzbund (Republican Protection League), which was established in 1923 to defend the constitution of the republic. As Friedrich Adler pointed out, this organisation was only meant to be a defensive measure from its inception, preserving the progress of the revolutionary period before the bourgeois counterrevolution. ${ }^{74}$

\footnotetext{
$72 \quad$ Compare Leichter 1964, p. 28.

73 Compare Zöllner 1979, p. 509.

74 See Adler 1923, Rede auf der Sitzung der Roten Garde, in the archival sources in the references section.
} 
In a sense, this adverse balance of forces, which neither the leadership nor the rank-and-file membership of the party were ever fully aware of, had already dictated the defeat of Social Democracy from the beginning. However, it was a great surprise for party leaders in 1927. While it had been an electorally successful year, it nonetheless saw the defeat of the party's strategic line and a crisis for democracy. The beginning of the crisis was marked by a skirmish between the Republican Protection League and the Front Fighters' Union on 23 January 1927, where the eight-year-old Josef Grössing and the disabled war veteran Matthias Csmarits were killed. In response to the acquittal of the perpetrators on 14 July 1927, the workers of Vienna staged a demonstration the following day, and there was a case of arson at the Palace of Justice. This fierce epidemic of workers' protest can be attributed to the following: the SDAP's defensive attitude regarding the acquittal of the killers; poverty and unemployment in the ranks of the proletariat in spite of the economic upturn; lenient court sentences in murder cases where the victims were left-wingers; and the SDAP's inability to take advantage of its electoral successes. In the course of fighting between the protesters and police under the command of Johann Schober, 89 people lost their lives - among them, five members of the SDAP executive and four police officers. 491 were injured. ${ }^{75}$ The day became a milestone on the path towards the authoritarian state order as desired by Chancellor Seipel, who, according to Renner, counted on 'the idea of murdering citizens as political principle. ${ }^{76}$ The freedom to protest had been infringed, and the time had truly arrived for the ideas of Linz to be put into practice. Yet the SDAP leadership with Bauer at its helm limited itself to a one-day general strike and a statement proposing that the Social Democrats participate in the government coalition, which was not a timely suggestion in consideration of the political situation. The SDAP also refused to arm protesters. ${ }^{77} 15$ July exposed the flaws of the party leadership, its lack of will and decisiveness to make use of the spontaneity of the working masses. Adding insult to injury, the protestors were reprimanded for breaking party discipline at the October 1927 party congress. ${ }^{78}$ Furthermore, the party's poor engagement with the masses

75 At the time, Bauer, Karl Seitz and Julius Deutsch engaged in talks with the chief of police, Johann Schober. See Leichter 1964, p. 53.

76 Our translation, cited after Braunthal 1976, p. 21.

77 In 1927, the party had 60o,0oo members and 1.5 million voters. Because of the prevailing belief in its own strength, it thought itself safe and did not expect that the government would use force.

78 See Protokoll des sozialdemokratischen Parteitages von 1927 under 'Documents, programmes, protocols' in the references section. 
and insufficient response to the popular mood became apparent. However, the defeat of the workers' movement did not shatter Bauer's faith that the party's strategy was correct. ${ }^{79}$ During Bauer's indictments against the government in parliament and at the October congress, he did, however, admit to two mistakes with a deep sense of guilt: he regretted abandoning the mobilisation and neglecting to mobilise the Schutzbund in order to protect the demonstrations. However, he was not fully convinced that the constitution had been broken. In his public speeches, his fear of provoking a civil war prevailed. ${ }^{80}$ At the time, he petitioned against driving a harder political line, arguing at odds with historical realities. He claimed that the strength of the workers' party had grown in opposition, and that fascism did not constitute a threat. In his political naiveté, he even went so far as to call for the disarmament of political parties, which proved he underestimated the power of the police and military of the bourgeois state. It is difficult to say with certainty whether Bauer was aware of the contradictions between his way of thinking and his political practice, and to what extent. Faced with an urgent possibility of further bloodshed, the intellect triumphed over the will, which proved the SDAP's loyalty to state institutions. In practice, it also meant victory for Seipel and a reinforced Heimwehr. As Renner observed, Bauer's decisions were coloured by his 'strength of character, his earnest, unbending adherence to his convictions'. ${ }^{81}$

In late 1927, a wave of repression against the working class, which had been protesting against the restriction of civil liberties and social legislation, heightened further. After the events of 15 July, the public expected that paramilitary organisations would be disarmed, yet the opposite took place. With increasing frequency, squads were involved in skirmishes that jeopardised the normal functioning of the state. In their trust in the power of the mass party, the SDAP leaders failed to recognise the growing counter-offensive of bourgeois forces and restricted themselves to criticising government policies in parliament. They rejected the February 1927 proposal of the KPÖ, which offered to support the SDAP in the forthcoming elections considering the growing fascisisation of the country. The SDAP did not want to endanger party unity by associating with a party that was irrelevant in Austria. ${ }^{82}$ The sole issue that the leaders of the respective party wings - Renner, Bauer and Max Adler -

79 At the conference of the metal industry federation, Bauer explained that the position of the party was determined by its recognition of the balance of forces in Europe - i.e. the lack of revolution.

8 o See e.g. Bauer 1976k, pp. 698-729.

81 Our translation, quoted from Braunthal 1976, p. 23.

82 1927, the крӧ had 3,00o members - see Burian 1974, p. 21. 
agreed on was their negative assessment of fascism as a counter-revolutionary and anti-democratic movement. However, their views on potential anti-fascist strategies were wildly divergent. Renner merely considered a coalition with the Christian Socials, underestimating both the power of the organisation and the intrinsically different interests it represented. Bauer solicited for a 'wait and see' policy, while Max Adler argued for violent measures, a mobilisation of the revolutionary forces of the proletariat and co-operation with the Communists. However paradoxical this may sound, groups on the centre and left of the Christian Social Party had a more realistic view of the danger posed by Austria's fascisisation than did the SDAP.

The danger of a fascist victory in Austria was made more acute by the economic and political consequences of the world crisis from 1929-31. It hit Austria particularly hard: industrial production fell by 39 percent compared to the previous year (and by 47 percent by 1934), while foreign trade decreased by 47 percent. The debt of domestic industries rose due to government investment in international bank credit in the Balkans, which only exacerbated the economic crisis. The critical situation of the banks reached its peak with the bankruptcy of Austria's largest bank, the Creditanstalt, on 16 June 1931. The working class was hit the hardest by the fall of real income by 30 percent and rise of unemployment by 25 percent (44.5 percent among industrial workers) compared to the years $1924-8 .^{83}$ Young people were pushed into a particularly desperate situation. ${ }^{84}$ From $1929-36$, Bauer was the only Social-Democratic politician to investigate the economic crisis. He made an effort to explain the causes of crisis and analyse its consequences for different economic groups. Based on his studies of the development of capitalism after the war, Bauer authored two works, Kapitalismus und Sozialismus nach dem Weltkrieg. Bd. I Rationalisierung - Fehlrationalisierung (Capitalism and Socialism after the World War, Vol. 1: Rationalisation - Mistaken Rationalisation, 1931) and Zwischen zwei Weltkriegen (Between Two World Wars, 1936), the latter of which was published during his emigration to Bratislava. In these two studies, Bauer illustrated the impact of the development of productive forces and relations of production on the process of capital and concentration of agriculture. He recognised the aftereffects of these changes, i.e. the social dynamics within organised capitalism.

83 Compare Maderthaner 2004, p. 61.

84 In 1918 after the fall of the monarchy, German-speaking public servants and teachers who returned to Austria filled the ranks of the unemployed, as the situation of the middle classes grew worse. The First Republic saw a consistent rise of the unemployment rate: 160 ,ooo in 1923; 276,00o in 1927; 500,00o in 1930-1; 770,00o in 1934. See Löw, Mattl and Pfabigan 1986, p. 32. 
The crisis exaggerated anti-democratic sentiments among the representatives of big capital, aristocratic landowners, petty bourgeoisie and peasantry. Carl Vaugoin, head of government since April 1931, inflamed the anti-democratic political direction. The Catholic Church, too, advocated a ban on Social Democracy from the political stage - it believed a Christian corporate state without Social Democracy or civil war were the only two alternatives. ${ }^{85}$ In the face of a real threat of fascisisation in 1931, which neither Bauer nor Renner fully acknowledged, Seipel offered the SDAP the chance to form a coalition government on 19 June 1931. He suggested Bauer for the post of vice chancellor despite not holding him in great esteem as a politician. The leading politicians of the SDAP - Bauer, Renner, Seitz and Robert Dannenberg - rejected this offer for ideological reasons, thus squandering the last opportunity to change Austria's domestic and foreign policies and preserve the social gains of the revolutionary period. With full confidence in working-class resistance, they merely convened the fourth congress of the Labour and Socialist International (LSI) in Vienna from 25 July-1 August 1931. Bauer drafted the resolution adopted by congress. It announced the necessity for the working class of Western European countries, mainly Germany and Austria, to take revolutionary measures in order to avert the danger of fascism. When designing this resolution, Bauer began from a false premise. Because he believed that the German proletariat would not allow for the fascisisation of its country, he envisaged the working class as leading the struggle against National Socialism. Furthermore, he hoped that the German workers would co-operate with the government and thus prevent Adolf Hitler from taking power. ${ }^{86}$

In view of the marginal practical significance of the resolution passed at the fourth LSI congress, the SDAP leadership announced in 1932 that it was prepared to form a coalition government with the bourgeois parties. Although with 72 of 165 seats the Social Democrats were still the most substantial force in parliament, basic premises for a coalition government were non-existent: rightwing groups were in control of the bourgeois parties, and on 6 May $193^{2}$ Karl Buresch's powerless government resigned. Engelbert Dollfuss, who represented the right wing of the Christian Social Party, was entrusted with forming a new government. On 25 May 1932, a government consisting of the Christian Socials, the Landbund and the Heimatblock, which was backed by the Heimwehr, was formed. ${ }^{87}$ The support of the Heimwehr, whose leader Emil Fey became

\footnotetext{
85 See Schöpfer 1929.

86 See Bauer 1976o, p. 164 .

87 The Landbund (countryside alliance) emerged out of the German-Austrian Peasant Party
} 
vice chancellor, was imperative for Dollfuss because the new government was formed with a majority of only one vote. Dollfuss had remained faithful to his promise to the Heimwehr and the forces of big capital that he would transform Austria into an authoritarian state. ${ }^{88}$ In the new corporate state, ideologically based on the papal encyclical, Quadragesimo anno, bourgeois democracy was completely annihilated. A number of repressive measures led up to the fall of democracy: a ban on regional elections; restrictions on the freedom of the press and independence of the judiciary on 7 March 1933; the dissolution of parliament effected by Dollfuss and the police on 15 March 1933; a ban on the operations of the Schutzbund on 30 March 1933; the arrest of KPÖ leaders and the liquidation of their party on 26 May 1933, the ban of the NSDAP in June 1933; the weakening of the position of the SDAP in the self-governing social security bodies from February 1933 onward; and the abolition of industrial councils

formed in 1920. Its base was the protestant peasantry. The Landbund stood out among national parties because it was ideologically homogenous and put forward its own slate. It also took up coalition work with parties that wished to preserve parliamentary democracy - in the First Republic, this meant co-operation with the SDAP, as well as the Christian Socials and Greater Germans. The Landbund was hostile to the Heimwehr and NSDAP. It quickly identified its participation in the Dollfuss government, which pursued an openly anti-democratic politics, as a mistake. Consequently, it left the political stage in 1933.

1918-29: consolidation of the bourgeois parties at home after a transitional revolutionary period;

1929-33: the state-presidential stage;

1933-4: the stage of constitutional and social corporate order;

1934-6: an autocratic state based on the corporate constitution coupled with the Heimwehr's immanent extremism;

1936-8: an autocratic state sketchily based on the corporate constitution in coalition with Austrian National Socialism.

Compare Kluge 1984. According to Gerhard Botz, an expert on Austria's period of fascisisation, one can distinguish four phases of the Austrian Ständestaat (corporate state):

I. Phase of the late parliamentary government (May 1932-March 1933);

II. Phase of the authoritarian semi-dictatorship and increasing fascisisation (until January 1934);

III. Phase of the developed semi-fascist authoritarian dictatorship (until October 1935 or mid 1936);

IV. End phase of partial de-fascisisation and bureaucratically ossified corporatism. Compare Botz 1984, p. 320. 
in state enterprises on 23 November 1933 and the Arbeiterkammer (workers' chamber) in December 1933, followed by the dissolution of the latter on 27 June 1938.

The solutions offered by Bauer and his comrades during this year, which was so decisive for the Austrian workers' movement, did not meet the expectations of party members and sympathisers. While the working class staged spontaneous demonstrations to protest against the dissolution of parliament, the party leadership could not agree on proclaiming a general strike. At that time, the SDAP was bigger than the Social Democratic Party of Germany, had greater social weight, had preserved its unity, and did not have to consider the influence of the KРÖ. The only objective justification for the political passivity of its leadership was the fact that the SDAP's electoral support base was concentrated in Vienna, Lower Austria and Styria since industrial areas, unlike in Germany, were dispersed across the entire country. Provinces averse, even actively hostile, to the socialists surrounded these territories. Even so, the working class was more internally consolidated and better armed in March 1933 than would be the case a year later, as Bauer confirmed in Der Aufstand der österreichischen Arbeiter (The Uprising of the Workers of Austria, 1934). Indeed, 1934 saw workers build barricades in an act of desperation to save the remains of a dying democracy. The fall of democracy was largely due to political rather than economic factors. Among them were a weak parliamentary practice, the ossification and bureaucratisation of political parties, offers of co-operation being rejected, the personal charisma of politicians of an authoritarian proclivity, the SDAP leadership's erratic assessment of possibilities to evoke support from the middle classes, the political ambitions of the church, and, not least, the Social Democrats' excessive willingness to compromise, a tendency which dominated in Bauer's positions. In 1933, he fought for a coalition government, and in order to achieve such co-operation, he even amended his official, if not actual, position concerning Anschluss. Bauer's suggestion to the Christian Social Party to wage a common struggle against fascism in March 1933 led to discord within the SDAP. ${ }^{89}$ Dollfuss rejected the offer, yet this did not stop Bauer from believing in the potential of an understanding until January 1934 and attempting to convince the chancellor of co-operation - he was prepared

89 As Butterwegge states, the autumn of 1933 saw the formation of a partyist left for the first time since the end of the war. Under the leadership of Ernst Fischer and Ludwig Wagner, it criticised what it regarded as 'Austromarxist fatalism', defensive methods of struggle, fear of foreign intervention and compromise with the government. At the SDAP congress in 1933, the left was a minority. It dropped its resolution, which called for active struggle, not least in order to preserve party unity. See Butterwegge 1990, pp. 463-5. 
to pay the price of concessions and endure the corporate state.$^{90}$ In March 1933, Dollfuss took up negotiations with Hitler. Bauer feared an alliance of Christian Socials, the Heimwehr and the NSDAP against Social Democracy, as well as civil war, and urged to resolve the conflict peacefully. Like many fellow Austrian politicians, he was taken by surprise: after failed negotiations with Hitler, the Dollfuss government's foreign policies took a sharp turn when it sought Benito Mussolini's support in April 1933. As a condition, the Italian Duce demanded that Dollfuss establish a fascist dictatorship and end the Marxist peril. Swiftly reacting to this request, the Heimwehr, which had strong bases in Upper Austria, Tyrol, Styria, Vorarlberg and Burgenland, increased search operations for weapons, which led to the destruction of printing presses and demolition of Social-Democratic party offices. The party's emergency congress, which convened in October 1933, proved politically irrelevant due to the divisions within the party. The right wing with Renner as its principle spokesman regarded the struggle against the Heimwehr and NSDAP as political suicide. The left, while sharply criticising the compromising stance in Bauer's address to congress, did not display much fighting spirit either. It justified its concessions and willingness to settle the conflict constitutionally by insisting on the need to preserve party unity. ${ }^{91}$ A psychologically vital factor was the fact that the party considered the Dollfuss government to be a 'lesser evil' in comparison to Hitler's assumption of power in Germany, while the Communists thought of both dictatorships as equally destructive. The goals that the party set itself at the emergency congress were unrealistic. Faced with the fascisisation of the country and a moribund democratic life, it demanded that popular representation be reconvened, jobs created for 200,000 unemployed, freedom of assembly, coalition, and the press reintroduced, and fascist hit squads disarmed. ${ }^{92} \mathrm{An}$ important novelty: all delegates pleaded for an autarkic, neutral Austria and wished to remove the demand for Anschluss from the party programme. The latter was merely of propagandistic and moral importance given the balance of forces in Europe. For the case that the government adopted a fascist constitution, banned the activities of the SDAP and trade unions, and established a 'provisional administration' in Vienna, the congress resolved to proclaim a general strike. Bauer distanced himself from the resolution in his speech. Given the economic and political crisis, he did not think that a strike would have any chance of success. He blamed the defeat of the workers' movement in Austria

\footnotetext{
90 Contrary to the interests of the working class, Bauer endorsed Dollfuss's ambitions in a series of 1933 articles in the Arbeiter-Zeitung.

91 Jedlicka and Neck 1975, pp. 365-8.

92 See Bauer 1978c, p. 695 .
} 
on the German workers' movement, and still did not believe that the government would outlaw the Social-Democratic party.

In January 1934, Fey announced a ban on the SDAP. ${ }^{93}$ Mussolini sent an emissary to Austria to convince the Dollfuss government of the need for a final confrontation with the Social Democrats. ${ }^{94}$ On 10 February 1934, the illegal кРӧ issued a leaflet calling for a general strike and change of government. The leader of the Christian trade unions, Leopold Kunschak, identified the threat of imminent civil war, appealing in vain to the Social Democrats to resist fascism together. ${ }^{95}$ The workers felt betrayed by their party. Since 1933, the period of greatest unemployment, only 40 percent of those without work had been receiving unemployment assistance, which was further reduced. In addition, their political rights had been confiscated. On 12 February, the Schutzbund engaged in open struggle against the forces of the Heimwehr, police and constabulary without prior communication with the SDAP. The insurgents found themselves in a dire situation. Fearing unemployment, they were leaving the barricades in the mornings to go to the factories, they were lacking arms, food and medication, and the combat operations were inadequately coordinated. In his memoirs, Wilhelm Ellenbogen wrote that Bauer felt personally responsible for the failure of the SDAP's political line, the lonely struggle of the Schutzbund, and the death of hundreds of people. ${ }^{96} \mathrm{He}$ recognised the bloody end of the Social-Democratic movement of the First Republic as his own failure and a tragedy from which he would not recover until his death. His bad conscience was made worse by the fact that he had fled Austria on the second day of the uprising, fearing arrest. ${ }^{97}$ On his day of departure, Bauer joined Deutsch and headed for the outskirts of Vienna to meet the Schutzbund fighters, yet they were unable to pass the police cordon. As Hanisch states, Bauer and Deutsch boarded a car on the 13 February 1934 and, guarded by Ernst Paul and Joseph Plely, crossed the Austrian-Czechoslovakian border heading for Bern. ${ }^{98}$

93 He would assume leadership of the ministry of defence and police in February.

94 See Secret letter exchange between Mussolini and Dollfuss in Letters.

95 See Rede L. Kunschak vom 9. Februar 1934 im Gemeinderat Wien in Archival sources.

96 See Ellenbogen 1983, p. 120.

97 Hanisch explains Bauer's behaviour by way of a panic attack. See Hanisch 2011, p. 305.

98 See Sporrer and Steiner 1983, p. 6o; Braunthal 1976b, p. 12; Hanisch 2011, p. 305. Steiner states that from 1934-8, about 2,00o people found refuge in Czechoslovakian territory (Schutzbund fighters, socialists, Communists). The Social Democratic Party of Czechoslovakia largely provided financial support. During the Stalinist period, many of them were accused of espionage and arrested. In 1936-7, a significant percentage of them went to Spain and enlisted with the International Brigades. See Steiner 1984, pp. 535-40. 
Upon emigrating, Bauer and Deutsch founded the Foreign Office of Austrian Socialists (ALÖs) with Bauer as chair. ${ }^{99}$ It served to support the families of fallen Schutzbund members and the illegal socialist movement forming in Austria financially. Out of this emerged a party, the Revolutionary Socialists of Austria (Rs). ${ }^{100}$ The Arbeiter-Zeitung and Der Kampf, both relaunched by Bauer, were the advisory organs of this movement, and the first issue of the Arbeiter-Zeitung was published as early as 25 February 1934. Bauer greeted the initialisation of the new party with enthusiasm and without attempting to act as a decisive influence in this organisation. He perceived himself to be a defeated leader: although the young party considered him a moral authority, he demanded that it - if not consistently until the end - issue a new general line and disassociate itself from the mistakes of Austromarxism. ${ }^{101}$ His study from this period, Die illegale Partei (The Illegal Party), offered a new system of judgement, a critical assessment of the old party, and a draft for illegal work close to the Bolshevik model. ${ }^{102}$ The necessity to change the forms of internal party life, educate members, and establish conspiratorial methods of action took centre stage. The text not only testified that Bauer re-evaluated the old doctrine and expanded his political consciousness, but also contained a revolutionary message. Bauer advocated that the dictatorship of the proletariat be rehabilitated under the existing balance of social forces and the approach to the Communist movement be modified. ${ }^{103}$

Bauer had already attended to the question of drafting a new strategy for the international workers' movement in the early 1930s. However, only when analysing his experiences and mistakes in exile did he conclude that united action of different working-class tendencies alone had the potential to overcome fascism. The concept of 'integral socialism' as outlined in Bauer's text, Between Two

99 Upon immigrating to Czechoslovakia, Bauer severed his ties with Renner, who had rejected his proposal to collaborate with the illegal movement. In 1934, Bauer vigorously criticised one of Renner's articles from the Neue Wiener Tagblatt, in which Renner had endorsed Hitler's annexation of Austria.

100 Among its members were Oscar Pollak, Manfred Ackermann, Otto Leichter, Joseph Buttinger, Rosa Jochmann, Roman Felleis, Karl Holoubek, Fritz Rauscher and Karl Seiler.

101 In 1934, he wrote to the Revolutionary Socialists from Bern: 'There is no doubt that we committed mistakes ... I can confess to my mistakes even more because I do not incriminate anybody else. For I am more responsible for the mistakes that have been committed than anybody else' (our translation) - Singer 1979, p. 125. See also Braunthal 1976n, p. 14 .

102 It was posthumously published by Friedrich Adler in 1938.

103 Bauer appealed to an established reality: back in Austria, the representatives of the former party left had argued in favour of a united front with the Communists as early as 1934. 
World Wars, was based on a positive, but also idealistic and wishful assessment of the trajectory of social transformation and the construction of socialism in the Soviet Union. Bauer did not approve of the general drift to the right of parties that belonged to the Labour and Socialist International, nor did he share their concerns about co-operating with the Third International. Admittedly, his proposal of co-operation between the two tendencies had little hope of success. The Communists were optimistic that the world economic crisis would initiate the world revolution and fall of capitalism, thus proving the Social-Democratic strategy wrong. Indeed, they laid the blame for the social and political consequences of fascism on the LSI parties. In 1924, they had coined the memorable phrase 'social fascism' to describe Social Democracy. The conference of the LSI international from 13-16 November 1935 rejected mutual participation with the Communist International in support of the workers' struggles in Spain. They also refused Bauer's suggestions to instigate contact between the respective executive and form a united struggle against fascism out of fear of a potential German attack against the Soviet Union. ${ }^{104}$ To justify this, it evoked concern that broader social layers might change sides and join the fascist camp. Bauer was ambiguous on the controversies between Social Democrats and Communists. On the one hand, at the LSI conferences he attempted to convince its leaders to initiate co-operation with the Comintern. On the other, he feared that the LSI might lose its ideological identity and organisational unity.

After Hitler's invasion of Czechoslovakia and the dissolution of the ALös, Bauer was forced to leave Bern. In May 1938, he took a plane to Paris alongside the leader of the KPÖ, Johann Koplenig. ${ }^{105}$ At the time, Julius Deutsch, Otto Leichter, Oscar Pollak and Joseph Buttinger were already staying in Paris, and the Foreign Office of Austrian Socialists was founded upon their initiative. At the party congress in Brussels, the Revolutionary Socialists decided to entrust Bauer with the leadership of the Rs. ${ }^{106}$ In Paris, Bauer founded a new journal, Der sozialistische Kampf, with three issues produced under his direction. Two days before his death, he participated in a meeting between confidants in the Montmartre district. As Berczeller remembered, the hoary and apathetic

104 Compare Löw 1980, p. 205.

105 Bauer went to Paris with great reluctance. Leichter remembered those moments as follows: 'As we drove from Brussels to Paris in early April, I sensed this deep sadness in him. I tried to distract by hinting at the beauty. "It is not as beautiful as home", Bauer said (...) "You will see it again", I tried to console him. "I will never see my home again", he replied, "do you really believe I could pick up where I left off on 12 February 1934?"' (our translation) - see Leichter 1970, p. 15.

106 See Weinzierl 1984, p. 10. 
Bauer looked old for his 57 years. ${ }^{107}$ Nevertheless, he did not stop writing and publishing until his final hours. His last two articles were grief-stricken moral demands. In 'Nach der Annexion' ('After the Annex'), he called for a critical instead of reactionary approach to Austria's Anschluss: a common struggle against fascism alongside the working class of Germany. 'Ich appelliere an das Gewissen der Welt' ('I Appeal to the Conscience of the World'), which he wrote just hours before his death, was dedicated to the 300,000 Austrian Jews and mass deportations to Dachau concentration camp. He pleaded to save those who were targeted by the fascist terror.

The material presented in this chapter contains only the most important events in Bauer's vast theoretical and political activity and political direction of the SDAP. Readers will find that the following chapters examine these themes in more detail, yet we will sometimes need to reacquaint ourselves with this basic chronology - after all, it is impossible to abstract the philosophical, social, and political concepts of a dedicated socialist from his practical actions.

107 See Leser and Berczeller 1977, p. 140. 